\title{
Pre-Mesozoic Alpine basements- Their place in the European Paleozoic framework
}

\author{
Jürgen F. von Raumer ${ }^{1, \dagger}$, François Bussy ${ }^{2, \dagger}$, Urs Schaltegger ${ }^{3, \dagger}$, Bernhard Schulz ${ }^{4, \dagger}$, and Gérard M. Stampfli2, \\ ${ }^{1}$ Département de Géosciences, Université de Fribourg, 6, Chemin du Musée, CH-1700 Fribourg, Switzerland \\ ${ }^{2}$ Earth Sciences Institute (ISTE) Geopolis, CH-1015 Lausanne, Switzerland \\ ${ }^{3}$ Section des Sciences de la Terre et de l'Environnement, Université de Genève, rue des Maraîchers 13, Ch-1205 Genève, Switzerland \\ ${ }^{4}$ Institut für Mineralogie, Brennhausgasse 14, D-09596 Freiberg/Sachsen, Germany
}

\section{ABSTRACT}

Prior to their Alpine overprinting, most of the pre-Mesozoic basement areas in Alpine orogenic structures shared a complex evolution, starting with Neoproterozoic sediments that are thought to have received detrital input from both West and East Gondwanan cratonic sources. A subsequent Neoproterozoic-Cambrian active margin setting at the Gondwana margin was followed by a Cambrian-Ordovician rifting period, including an Ordovician cordillera-like active margin setting. During the Late Ordovician and Silurian periods, the future Alpine domains recorded crustal extension along the Gondwana margin, announcing the future opening of the Paleotethys oceanic domain. Most areas then underwent Variscan orogenic events, including continental subduction and collisions with Avalonian-type basement areas along Laurussia and the juxtaposition and the duplication of terrane assemblages during strike slip, accompanied by contemporaneous crustal shortening and the subduction of Paleotethys under Laurussia. Thereafter, the final Pangea assemblage underwent Triassic and Jurassic extension, followed by Tertiary shortening, and leading to the buildup of the Alpine mountain chain.

Recent plate-tectonic reconstructions place the Alpine domains in their supposed initial Cambrian-Ordovician positions in the eastern part of the Gondwana margin, where a stronger interference with the Chinese blocks is proposed, at least from the Ordovician onward. For the Visean time of the Variscan continental collision, the dis-

"E-mails: Juergen.vonRaumer@unifr.ch; francois bussy@unil.ch; urs.schaltegger@unige.ch; Bernhard .Schulz@mineral.tu-freiberg.de; Gerard.Stampfli@ unil.ch tinction of the former tectonic lower-plate situation is traceable but becomes blurred through the subsequent oblique subduction of Paleotethys under Laurussia accompanied by large-scale strike slip.

Since the Pennsylvanian, this global collisional scenario has been replaced by subsequent and ongoing shortening and strike slip under rising geothermal conditions, and all of this occurred before all these puzzle elements underwent the complex Alpine reorganization.

\section{INTRODUCTION}

In the more than $200 \mathrm{yr}$ of identification of pre-Mesozoic basement elements in the Alpine orogen, Ebel (1808) was the first to display the Alpine basement areas and outcrops of the northern foreland with the same color; Desor (1865) defined the Alpine basement realms (Helvetic, Penninic, Austroalpine, Southalpine) in their Alpine framework; and Niggli (1960) first outlined the contours of the Alpine overprint on the basement by mapping the zoned distribution of characteristic Alpine metamorphic minerals, evolving from the lowermost greenschist facies in the north to the amphibolite facies to the south.

The intensive geological field work performed by many groups between the cities of Graz (Austria) and Genova (Italy) led to the detailed reconnaissance of the Alpine collisional belt (e.g., Trümpy et al., 1980; Hunziker et al., 1992; Pfiffner et al., 1996; Frey et al., 1999; Schaltegger and Gebauer, 1999; Oberhänsli, 2004; Schmid et al., 2004; Handy et al., 2010) and the complex imbrication of preMesozoic basement blocks through large-scale nappe and strike-slip tectonics (Escher et al., 1997; Stampfli, 2001; Steck et al., 2001). This long-lasting research permitted the separation of pre-Permian basement relics hidden in the
Alpine deformational chain (von Raumer and Neubauer, 1993) from their Mesozoic sedimentary envelopes. After Zwart and Dornsiepen (1978) and Rast and Skehan (1983) considered the general relationship between European and transatlantic Cadomian basement areas, Ziegler (1984) proposed a peri-Gondwanan origin for some of the Alpine basement's constituents. Stampfli (1996) developed the first theoretical approach for a global geodynamic interpretation of this polyorogenic domain. In his definition of the "intra-Alpine" basement, he illustrated the complex global geodynamics bound to the evolution of the oceanic margins at the northern Gondwana margin during late Paleozoic evolution. The corresponding plate-tectonic evolution of the Alpine domain after Late Permian times has recently been revealed (Stampfli and Hochard, 2009). This palinspastic interpretation also enabled the recognition of the original preAlpine situation of the pre-Permian basement relics in the Alps.

Although many parts of the basement were highly overprinted during the Alpine metamorphic events, some areas (e.g., in the External massifs) were less affected, making it possible to recognize older lithologies and structures.

The aims of this paper are to summarize what is actually known about the pre-Mesozoic Alpine basement and to compare known preMesozoic Alpine basement units (Figs. 1 and 2) with the observed lithostratigraphic units of the larger Variscan framework. To this end, it is necessary to repeat certain previously published details. Consequently, we must describe the Paleozoic evolution of the future Alpine domains located at the interface of the supercontinents: Gondwana in the south and Laurussia in the north. The geodynamic reconstruction of the Alpine basement areas has much in common with crystalline basement areas of Central Europe and is regarded in the light of the newest plate-tectonic reconstructions (Stampfli et al., 


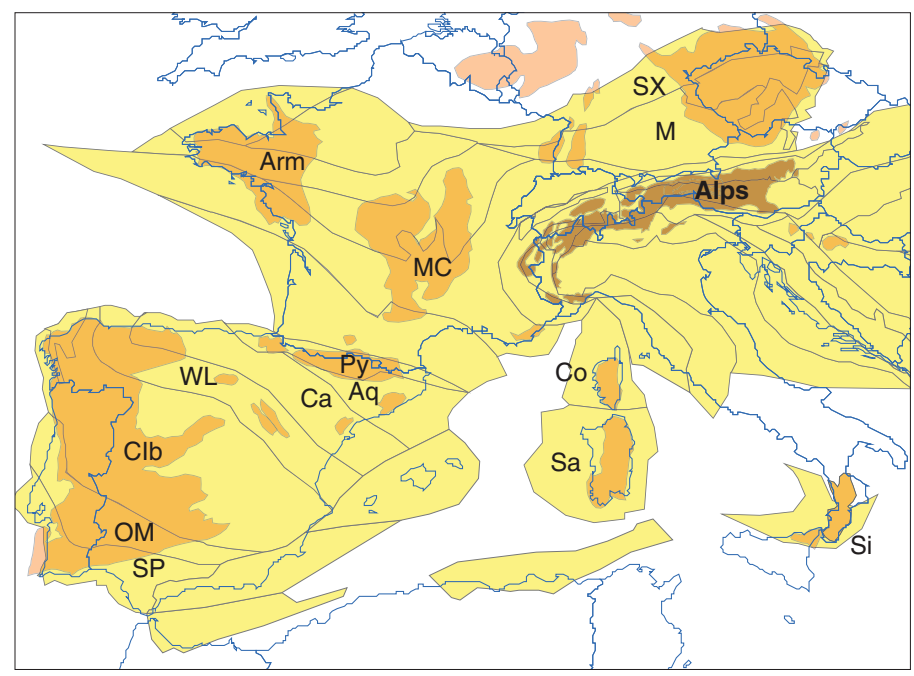

Figure 1. The pre-Mesozoic basement areas of the Alps (brown) and their present-day locations among the Central European Variscan basement areas (light orange) and Avalonian basements (pink). Terrane map with subdivision into geodynamic units (modified after Stampfli et al., 2006) (yellow), inspired by Franke (1989). For a better understanding and identification, the contours of the specific geodynamic units are used in the reconstructions. Aq-Aquitaine; Arm-Armorica; CaCantabrian terrane; CIb-Central Iberian; Co-Corsica; M-Moldanubian Units; MC-French Central Massif; OM-Ossa Morena; Py-Pyrenees; Sa-Sardinia; Si-Sicilian-Apulian basements; SPSouth Portuguese; SX-Saxothuringia; WL-West Asturian-Leonese zone. Blue lines-Geographic boundaries.

2011), which present constraints for new interpretations of its geodynamic evolution.

One of the major difficulties encountered when comparing pre-Mesozoic Alpine basements with those outside the Alps is the Alpine metamorphic overprint masking all the older structures. A strong understanding of basements outside the Alps must be accompanied by a recognition of the corresponding structures in the Alpine domain. It is also evident that these reconstructions have profited from the input of many new ages and geochemical data being included in the huge data set related to the reconstructions. However, difficulties arise when the field data are assembled. Although the timing of the collisions is usually quite well known according to sedimentary and metamorphic records, the kinematics of the terranes involved in these collisions are less clear, requiring the constraints of a database (Stampfli, 2012). Geodynamic units are currently defined according to their geodynamic scenarios in space and time and then assembled as building stones to form terranes. Plates are reconstructed by adding/removing material along the plate limits (Stampfli and Borel, 2002), where the appreciation of plate velocities is a major constraint in the kinematics of the involved terranes and continents. Although new constraints. the geological data were always put forward, at a certain stage the model enables choices based on plate-tectonic principles.

Consequently, the placing of Alpine basement areas in their former framework follows very different constraints and represents the major task of this paper, but this analysis will be subject to change when new data introduce

\section{PLATE-TECTONIC RECONSTRUCTIONS FOR PRE-VARISCAN RELICS}

Since the publication of the plate-tectonic model for the Paleozoic and Mesozoic (Stampfli and Borel, 2002), new concepts of the evolution of the Rheic Ocean (cf. Murphy et al., 2006; Nance et al., 2010) and the introduction of small geodynamic units (Hochard, 2008) instead of large "terranes" at the continental plate scale have influenced recent reconstructions. In the new model (which comprises a part of the Neftex Geodynamic Earth Model), Stampfli et al. (2011) strongly involved some of the so-called "Chinese blocks" in the evolution of the northern Gondwana margin. When Avalonia was separated from Gondwana during the opening of the Rheic Ocean (ca. $480 \mathrm{Ma}$ ) and collided with Baltica, the Hunic terranes (e.g., Karakum, Kunlun East, Pamir-Jinsha, Qaidam, Qilian, Turan; cf. von Raumer and Stampfli, 2008), which were formerly located at the eastern continuation of Avalonia, separated from the Gondwana margin during the opening of the eastern branch of the Rheic Ocean. They subsequently collided with the northern Chinese blocks and not with the Laurussia margin, as previously argued (Stampfli and Borel, 2002).

Like most of the European basement areas of Variscan age, those of the Alpine realm were believed to have a north Gondwanan origin (von Raumer, 1998), and the following evolution was proposed (e.g., Neubauer, 2002; Neubauer et al., 2002; Schätz et al., 2002; Stampfli et al., 2002; von Raumer et al., 2002):

(1) An active margin setting developed along the north Gondwana margin during the Neoproterozoic-Early Cambrian period contemporaneous with the Cadomian orogenic evolution (a compilation of ages is shown in Schaltegger, 1997a; Schulz, 2008; see Fig. 3).

(2) When the Rheic Ocean opened along the western margin of Gondwana, its eastern margin, which was more or less the site of the future Alpine basement areas, underwent a complex and not yet sufficiently resolved Ordovician evolution, including signatures of intra-arc magmatism with extension, subduction-collision, and the subsequent opening of the eastern branch of the Rheic Ocean.

(3) A passive margin setting developed after the Late Ordovician, and the crustal extension lasted until the opening of the Paleotethys Ocean during the Devonian.

\section{Precambrian Evolution}

Frisch and Neubauer (1989) first presented the concept of a Neoproterozoic-early Paleozoic active margin setting in the Penninic and Austroalpine basement. Substantiated by Schaltegger (1997a), and other contributions in the same volume, with geochemical and chronological data from the Silvretta, Scarl-Campo, and Ultental basements (for the location of Alpine basement areas, see Fig. 2), this database was further extended with data from the Tauern Window (Eichhorn et al., 1995, 1999, 2001) and the Austroalpine basement to the south of the Tauern Window (Schulz and Bombach, 2003; Schulz et al., 2004, 2008). According to Schulz (2008), the oldest magmatic protoliths of this period in the Alpine basement are dated at ca. $600 \mathrm{Ma}$, and they appear to be related to this Neoproterozoicearly Paleozoic active margin setting.

Alpine pre-Neoproterozoic history can be described by $\mathrm{Nd}$ and $\mathrm{Lu}-\mathrm{Hf}$ isotopic data, the 
Figure 3. Precambrian and Paleozoic events in the Alpine basement domains (modified after Schulz, 2008). He-Helvetic; $\mathrm{Pe}-$ Penninic; AA-Austroalpine; SA-Southalpine. Bold line between the $\mathrm{Pe}$ and $\mathrm{AA}$ marks position of Tertiary Alpine suture. Note the variable time scale to the left. Signatures: 1-intrusion of granites, tonalites, diorites, and gabbros (magmatic protolith zircon ages); 2-mafic extrusions, plutons, and dikes, ultramafic ophiolites (magmatic protolith zircon ages); 3-rhyolites; 4-pegmatites; 5-age populations of detrital and inherited zircons; 6-detrital minerals in early Paleozoic sequences (Ar-Ar mica ages); 7-metamorphic (dark-gray tone) and other geodynamic events (light-gray tone). The major stages of the pre-Mesozoic magmatic evolution in the Alpine basement can be grouped into a Carboniferous-Permian collisional and postcollisional stage (V), the Paleozoic active and passive margin settings (IV), Neoproterozoic breakup of the Gondwana margin (III), the Proterozoic mantle mobilization events (II), and the ArcheanProterozoic crustal mobilization event (I) recorded by detrital and inherited zircons.

the Bohemian Massif (Linnemann et al., 2007, 2008; Drost et al., 2010), the Austroalpine Ordovician-to-Devonian sediments in the Thurntaler Phyllite Group and Gailtal metamorphic basement display a striking difference among their many similarities: They contain a prominent zircon population with ages ca. 1.0 Ga (Siegesmund, 2011, personal commun.), which is nearly absent in the Bohemian Massif. These distributions are better understood when considering the provenance of detrital zircons from the eastern Gondwana areas, as discussed in our earlier papers (see following) and presented more recently by Meinhold et al. (2012).

Comparing the published $\varepsilon_{\mathrm{Nd}}$ values and model age data from Ordovician and Carboniferous acidic magmatic rocks from diverse Alpine basement areas with those discussed by Nance and Murphy (1994), we concluded (von Raumer et al., 2003, and references therein) that the Alpine basement was part of Cadomia (cf. Murphy et al., 2008; Nance et al., 2010). In addition, von Raumer et al. (2009) noted that sedimentary sources should be sought in both the commonly accepted west and central African shield, but also in eastern Gondwana and in the Chinese and Indian blocks. Depending on the length of the transporting rivers and taking

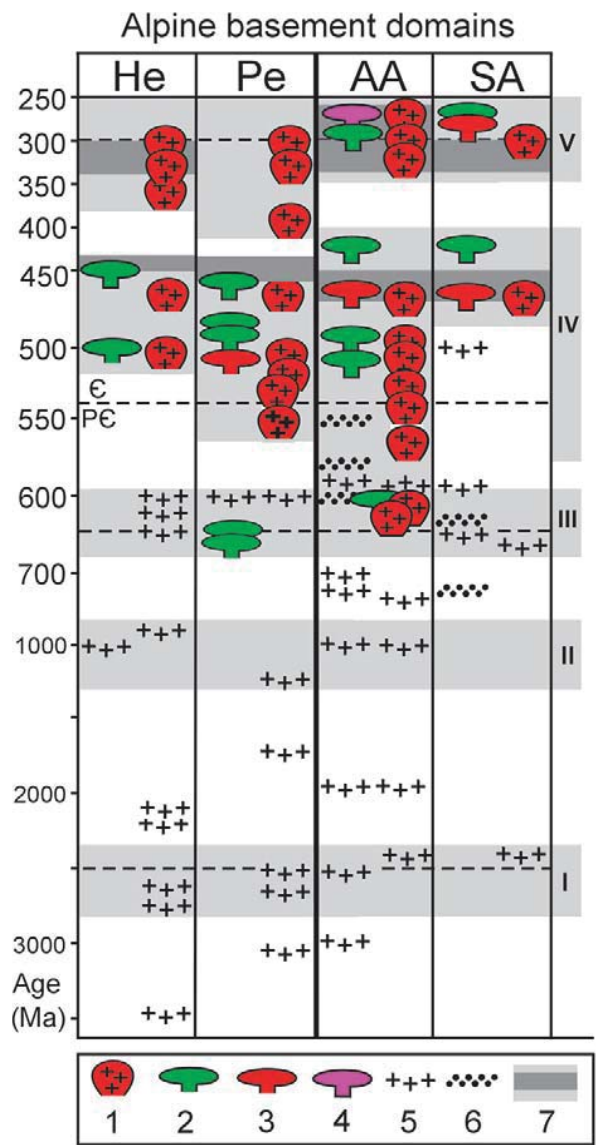

the different periods of sediment recycling into account, a wide variety of source areas should be considered. Detrital white micas from the Austroalpine and Southalpine Mississippian sediments document Devonian source areas for which the present-day outcrops are unknown (Neubauer et al., 2007).

\section{Cambrian-Ordovician Evolution}

Since the Cambrian-Ordovician, most Alpine basement areas have been involved in a major magmatic and sedimentary cycle (Fig. 3) accompanied by rather strong tectonic activity.

\section{Sedimentary Evidence}

Although they were strongly metamorphosed during the Variscan and Alpine orogenies, lithostratigraphic parallels remain recognizable among the pre-Mesozoic lithologies of the Alpine and European basement areas, respectively. Sediments of Cambrian ages have been noted in the Alpine domain by Schulz (2008) and Guillot and Ménot (2009); however, if they existed at all, their preservation is fragmentary, and their nature is variable due to their deposition in rifts. For example, the widely distributed "Erlan-felses" are calc- silicate lenses interpreted as relics of former Cambrian and/or Neoproterozoic carbonate horizons (von Raumer and Bussy, 2004); they outcrop as relics in the Saxothuringian and Moldanubian basement areas but are also common in all Alpine basement realms (illustrations: Arnold, 1970; von Raumer, 1976; Zurbriggen et al., 1997; Schulz et al., 2008). In addition, striking similarities exist between Neoproterozoic-Early Cambrian lithostratigraphic columns from the Saxothuringian domain (Delitzsch borehole: Ehling, 1993; Röllig et al., 1995; Buschmann et al., 2001) and amphibolite-facies metasediments from the Aiguilles Rouges basement (Chiaradia, 1993; von Raumer and Bussy, 2004), and most likely from the Aar and Gotthard Massifs. The Late Proterozoic-Early Cambrian sedimentary series from the Moroccan Anti-Atlas domain (von Raumer et al., 2002) are also very similar. In addition, all three areas host scheelite-skarns in the former Cambrian limestones. Their high-grade metamorphic equivalents, calcsilicate felses, have been mined for tungsten, and similar lithologies have been observed in the Appalachians (Einaudi et al., 1981). Similarly, metapelitic-metagraywacke series with interlayers of magmatic acidic rocks and finely layered tourmalinite beds from the Aiguilles Rouges area (von Raumer and Bussy, 2004) are very similar to those from the Central Iberian Neoproterozoic-Early Cambrian lithological sequences (Rodríguez Alonso et al., 2004).

Von Raumer and Stampfli (2008) identified three major events in the subsidence patterns of metasedimentary rock units along the northern Gondwana margin: crustal extension during the Neoproterozoic-Early Cambrian, rifting during the Middle and Late Cambrian, and inversion and accelerated rifting since the Ordovician (Floian). At $461 \mathrm{Ma}$ (Fig. 4), a general active margin setting is found in the Gondwana margin along the Hunian terrane assemblage (cf. von Raumer and Stampfli, 2008), including terranes accreted later onto the northern Chinese block (cf. Wilhem, 2010). They were separated from the Gondwana margin during the opening of the western branch of the Rheic Ocean; its contemporaneous rift structures received a great variety of detrital input (cf. von Raumer et al., 2006) that is generally related to the Armorican quartzite of Floian age. The Armorican quartzite, however, is older than the last rifting event that led to the opening of the eastern Rheic. The latter formed after a shortlived inversion phase of the preexisting horstand-graben system, either resulting from an intervening intra-oceanic arc or the transform fault discussed for the eastern part of the Gondwanan margin. 


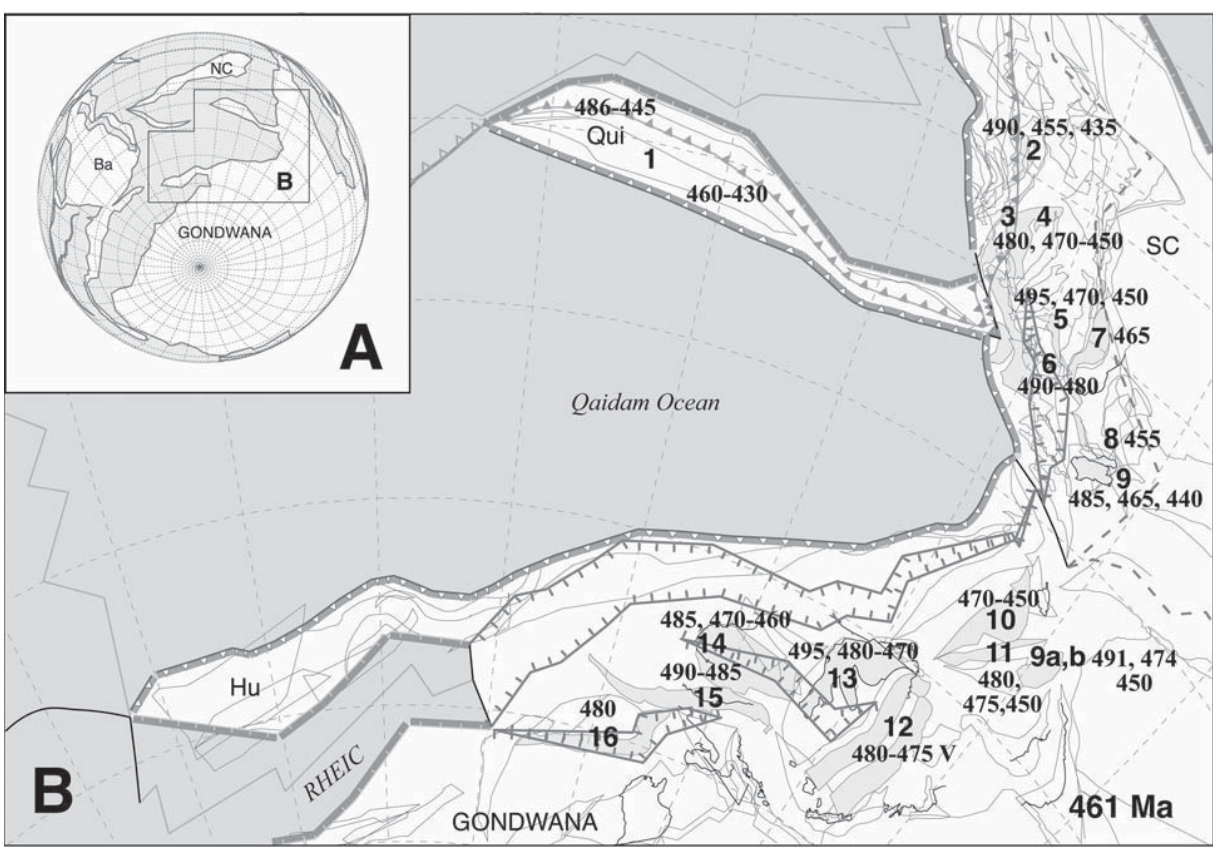

Figure 4. Ordovician magmatic events along the Gondwana margin. (A) Palinspastic Ordovician (461 Ma) reconstruction after Stampfli et al. (2011), showing the location of detail map B, with selected age data (in Ma) of the Ordovician magmatic pulses along the Gondwana margin. Numbers, indicating the geodynamic units in question, are referred to in Table 1 (additional information on more recent age data), and references for older data are found in von Raumer et al. (2002). The future Alpine geodynamic units (grouped under 3) in the frame of the Ordovician basement areas are located at the eastern limits of the Qaidam Ocean, spanning the Qilian basement in the north and the Hunic terranes (Hu) located at the Gondwana margin. The future eastern branch of the Rheic Ocean is not yet opened (rift structures: deposits of Early Ordovician detrital sediments). Specific basement areas: NCNorth China; Ba-Baltica; Qui-Qaidam; SC-South China. This figure derives in part from the Neftex Geodynamic Earth Model. Copyright Neftex Petroleum Consultants Ltd. 2011.

\section{Magmatic Evidence}

Since the Early Cambrian, the Gondwana margin has been dominated by an active margin setting (Stampfli et al., 2011), accompanied by rifting behind the margin and stretching from the more western (Iberian) to the more eastern (south Chinese) Gondwana margin, where the Alpine basements units are thought to have been located (Fig. 4; Stampfli et al., 2011). In this domain, a transform-type margin is believed to have complicated the general cordillera-like tectonic situation (see discussion).

After the Neoproterozoic-Early Cambrian, several magmatic pulses characterize the magmatic evolution at the Gondwana margin (490 Ma, 480-470 Ma, 460-450 Ma; Fig. 4; Table 1), followed by rather late magmatic manifestations ca. 440-430 Ma.

Alpine domain. Although the evidence is fragmentarily preserved, the basement areas of the Alpine domains also underwent this longlasting evolution, which is characterized by intrusions of granitoid and/or metabasic rock series at different times and crustal levels, lasting until the Silurian.

When discussing the origins of the Rheic Ocean, von Raumer and Stampfli (2008, with references) reviewed the many relics of a supposed Neoproterozoic-Cambrian arc stretching from the easternmost Ossa Morena zone to the westernmost parts of the Carpathians along the Gondwana margin. In light of the newest ideas on geodynamic evolution (Stampfli et al., 2011; Stampfli, 2012), such scenarios have to be revisited when considering that the geodynamic evolution during this early period consisted of both an active margin setting and the evolution of the intra-oceanic structures of areas spanning Iapetus and the more eastern oceanic domains.

For the Alpine areas, these older geodynamic settings are proposed mainly for the Austroalpine and Penninic realms. Reviewing the plate-tectonic scenario, Schaltegger et al. (1997) proposed a geodynamic model for the Austroalpine Silvretta nappe, consisting of an older generation of ca. $610 \mathrm{Ma}$ island-arc metadiorites (intra-oceanic) and subsequent 520-530 Ma eclogitized gabbroic and tonalitic melts intruding a continental (Gondwana) margin magmatic arc. They were followed by $500 \mathrm{Ma}$ oceanic plagiogranites (Müller et al., 1996) in a supposed forearc or backarc environment and the subsequent intrusion of gabbroic melts (475 Ma; Poller, 1997) in a collisional belt. A comparable scenario is valid for the Austroalpine domain south of the Tauern Window (Schulz et al., 2004), which is characterized by the elevated $\mathrm{Th} / \mathrm{Yb}$ values typical of subduction-related magmatism by 590 Ma normal mid-ocean-ridge basalt (N-MORB)-type eclogitic metabasalts. This scenario most likely represents an early stage of active margin evolution (intra-oceanic arc?) and 550-530 Ma volcanic arc metabasalts followed by metagabbros of ca. $477 \mathrm{Ma}$ (Loth et al., 2001).

In the lower Penninic nappes, Bussien et al. (2011) dated Cambrian metadiorites from a banded mafic complex (U-Pb zircon ages, 533 and $544 \mathrm{Ma}$ ), and Schaltegger et al. (2002) dated Cambrian (ca. $518 \mathrm{Ma}, \mathrm{U}-\mathrm{Pb}$ zircon age) oceanic magmatism in dismembered relics of mafic and ultramafic rocks, provoking a discussion of the possible lateral extension of such mafic-ultramafic associations in the Alpine domain. Ménot et al. (1988) dated 498 Ma plagiogranites in the Chamrousse ophiolite complex (Belledonne, External massifs), which may have presented a comparable mafic-ultramafic association. However, because this more isolated ultramafic body is thought to have been transported from a more external domain (Guillot and Ménot, 2009), it is equally likely to represent a former different geodynamic unit in the frame of the Iapetus evolution along the Gondwana margin, comparable to that discussed for the Saxothuringian domain (Linnemann et al., 2007). An interesting parallel can be observed in the NW Iberian $495 \mathrm{Ma}$ Bazar ophiolite (Sánchez-Martínez et al., 2012), which is thought to represent a relic of the Iapetus-Tornquist Ocean.

Additional data supporting an Ordovician subduction cycle were furnished from the Helvetic realm (Aar Massif; Schaltegger et al., 2003): A ca. 478 Ma gabbro was affected by high-pressure (HP) metamorphism and a subsequent high-temperature (HT) overprint before attaining partial melting during decompression at ca. $450 \mathrm{Ma}$. Gabbroic intrusions of $460 \mathrm{Ma}$ in the External Alpine massifs (Abrecht et al., 1995; Oberli et al., 1994; Paquette et al., 1989; Rubatto et al., 2001) also argue for the presence of a major crustal event along the eastern part of the Gondwana margin. An Ordovician subduction cycle (Franz and Romer, 2007) and the associated calc-alkaline igneous intru- 
sions (Bussien et al., 2011) are also discussed for the lower Penninic nappes. These scenarios correspond in age and geodynamic setting to bimodal, rift-related successions of the Ligurian Briançonnais domain (Gaggero et al., 2004) and to Cambrian-Ordovician intermediate and felsic volcanic rocks from the nappe zone in Sardinia (Oggiano et al., 2010). When compared to the general Gondwana margin setting, these parallels to the Neoproterozoic-Cambrian evolution were previously presented by von Raumer and Stampfli (2008).

The active margin setting in the Alpine domains is characterized by different pulses of calcalkaline granitoids between $480 \mathrm{Ma}$ and $450 \mathrm{Ma}$ (Fig. 4; Table 1) in most Alpine basement areas (Rubatto et al., 2001; von Raumer et al., 2002; Guillot et al., 2002; Schaltegger et al., 2003). The stepwise magmatic evolution in the Austroalpine basement to the south of the Tauern Window is documented by $470-450 \mathrm{Ma}$ I- and S-type granitoid intrusions (orthogneisses), followed by alkaline within-plate basalt to MORB-type mafic suites ca. $430 \mathrm{Ma}$ (believed to represent the rifting of Paleotethys; Schulz et al., 2008). Equally, in the Austroalpine Silvretta area (cf. Liebetrau and Nägler, 1994; Poller, 1997; Poller et al., 1997; Schaltegger et al., 1997), and after an Early Cambrian active margin setting, the Cadomian-type basement area was intruded by Late Cambrian to Early Ordovician so-called "older Orthogneisses" (ca. 470 Ma; Table 1) and gabbros under lower-crustal conditions before the main "Flüela granite" series intruded at ca. $420 \mathrm{Ma}$. In the external domain, the intrusion of granitoid and mafic rock suites (MORB tholeiites) between 470 and 450 Ma documents the Ordovician active margin (Bussy et al., 2011). Comparable events are observed in the southernmost Ligurian Alps (470-460 Ma; Gaggero et al., 2004).

The recently reported Ordovician backarc volcanics (enriched [E]-MORB gabbros and pillow lavas) from the Penninic Métailler domain (Table 1; Gauthiez et al., 2011) confirm the general active margin setting and transform zone of the Alpine domain. The question remains regarding whether the "Greenstone Unit," defined in the western part of the Aiguilles-Rouges massif (Dobmeier et al., 1999), is also a remnant of an early Paleozoic oceanic-island arc or whether this series should be attributed to a DevonianMississippian magmatic evolution.

Gondwana margin parallels. Interestingly, a comparable evolution is documented in both the adjacent Barrandian area of the Bohemian Massif (Chlupaĉ et al., 1998), which is thought to have been also located at the more eastern Gondwana margin, and in other adjacent areas (cf. Fig. 4; Table 1).
In a comparison of the magmatic evolution along the entire Gondwana margin (Fig. 4; Table 1), the rifting of the Cadomian basement leading to the opening of the Rheic Ocean in the western part of the Gondwana margin most likely began ca. $480 \mathrm{Ma}$, whereas the eastern branch began opening ca. $460 \mathrm{Ma}$. In the former, more western parts (e.g., Central Iberia, Armorica, and Saxothuringia, including the Polish Sudetes), the oldest granitoids, characterized by embayed phenocrystals of blue quartz, appeared during the earliest Ordovician (cf. Fig. 1B; 488 Ma-Stampfli et al., 2011). Since the description of the "Ollo de Sapo" granitoids (frog's eye; Parga Pondal et al., 1964), it has been known that these rocks contain a large number of blue-colored quartz phenocrysts with corrosion channels, indicating their early magmatic crystallization. Specific geological and petrographic descriptions were the subject of early doctoral theses (Schäfer, 1969; Plogmann 1973), and modern dating (e.g., Valverde-Vaquero and Dunning, 2000; Montero et al., 2007; Solá et al., 2008; Bea et al., 2010) finally established their Early Ordovician age (495-480 Ma). According to Díez Montes et al. (2010, p. 363), these rocks represented "volcanic domes, which underwent endogenous growth with subvolcanic, phenocryst-rich magma intruding and cooling under a volcanic and volcaniclastic shield." The heat causing the crustal melting was thought to have been supplied by mafic magmas intruding or underplating the lower crust.

The occurrence of the characteristic blue corroded quartz phenocrysts has previously been ignored as an argument for their deep-seated magmatic origin. According to Müller et al. (2009), the blue cathodoluminescence of quartz phenocrysts in late Variscan granites indicates a considerable enrichment of $\mathrm{TiO}_{2}$, characterizing the early crystallization of quartz at high temperatures. Experimental data by Johannes and Holtz (1996) point to low water activities and high crystallization pressures for these quartz phenocrysts before adiabatic cooling and partial magmatic resorption (Müller et al., 2009). Consequently, formation of these early granitoid melts should have occurred under lower-crustal conditions. Nearly identical rocks occur in the Saxothuringian domain (eastern Lausitz, Rumburk granite-Linnemann et al., 2000; Seifert et al., 2011; western Sudetes-Winchester et al., 2003), and their general intrusion ca. 495$480 \mathrm{Ma}$ in the entire domain is interpreted as the time of early rifting in the Gondwana active margin (cf. Fig. 1B; $488 \mathrm{Ma-Stampfli} \mathrm{et} \mathrm{al.,} \mathrm{2011).}$

Are granitoid rocks of the Ollo de Sapo type present in the Alpine domain? Von Raumer (1971) tentatively compared migmatized orthogneisses of presumed Ordovician ages hosting very large K-feldspar phenocrysts $(10-15 \mathrm{~cm})$ with Ollo de Sapo-type rocks from the Iberian areas exhibiting similar phenocrysts. However, the strong Alpine recrystallization of quartz did not permit a thorough comparison. Similar rocks may have existed in the Belledonne domain (Guillot et al., 2009) and in the Penninic Vanoise-Siviez Mischabel domain (Guillot et al., 2002). Interestingly, blue quartz is also observed in the Ordovician Mönchalp granitoids (older orthogneisses) from the Austroalpine Silvretta nappe (Poller, 1997), which are comagmatic with gabbroic rocks in a high-temperature environment (cf. Müller et al., 2009).

At the western Gondwana margin, this early magmatic event was accompanied by and nearly contemporaneous with the subsequent (ca. 480-470 Ma; Valverde and Dunning, 2000; Gutiérrez-Alonso et al., 2007; Linnemann et al., 2000; El Korh et al., 2012; Rubio-Ordóñez et al., 2012) calc-alkaline granitoids and acidic volcanics. Valverde and Dunning (2000, p. 15) suggested that the broadly coeval volcanism and plutonism "were part of a felsic magmatic belt which extended along the Ollo de Sapo of the Central Iberian zone," which is currently interpreted as the expression of a continental arc setting (Rubio-Ordóñez et al., 2012) during the Early Ordovician breakup of the peri-Gondwanan margin. It is noteworthy that the granitoid gneisses of this age group have been dated in the South Tiscia block (laser ablation [LA] sector field $[\mathrm{SF}]$ inductively coupled plasma-mass spectrometry [ICP-MS] zircon age; Starijaš et al., 2010) and in some Carpathian areas (see Fig. 4; Table 1), which are also believed to have been located at the eastern Gondwana margin at that time.

\section{Ordovician to Silurian Crustal Extension}

From the Middle Ordovician onward, crustal extension is recorded through the sedimentary evolution in the Alpine domain (Schönlaub, 1997; Neubauer et al., 2007). Sedimentary gaps and thermal uplift, as observed outside the Alpine domains (thermal uplift: e.g., Central Iberia East, Barrandian, Saxothuringian; von Raumer and Stampfli, 2008) and equally in the long-lasting volcanic evolution in the adjacent Barrandian area (Chlupaĉ et al., 1998), are thought to represent the general crustal extension regime. In the Pyrenees, Casas et al. (2010) dated a Late Ordovician volcanic event (Fig. 4; Table 1), testifying to extension and, in Sardinia, alkalic meta-epiclastites emplaced at $440 \mathrm{Ma}$ in the external nappe within the post-Caradocian transgressive sequence; these factors are attributed to the rifting and collapse of the Mid-Ordovician volcanic arc (Oggiano et al., 2010). 
TABLE 1. ORDOVICIAN AGE DATA AND REFERENCES FOR AREAS NUMBERED IN FIGURE 4

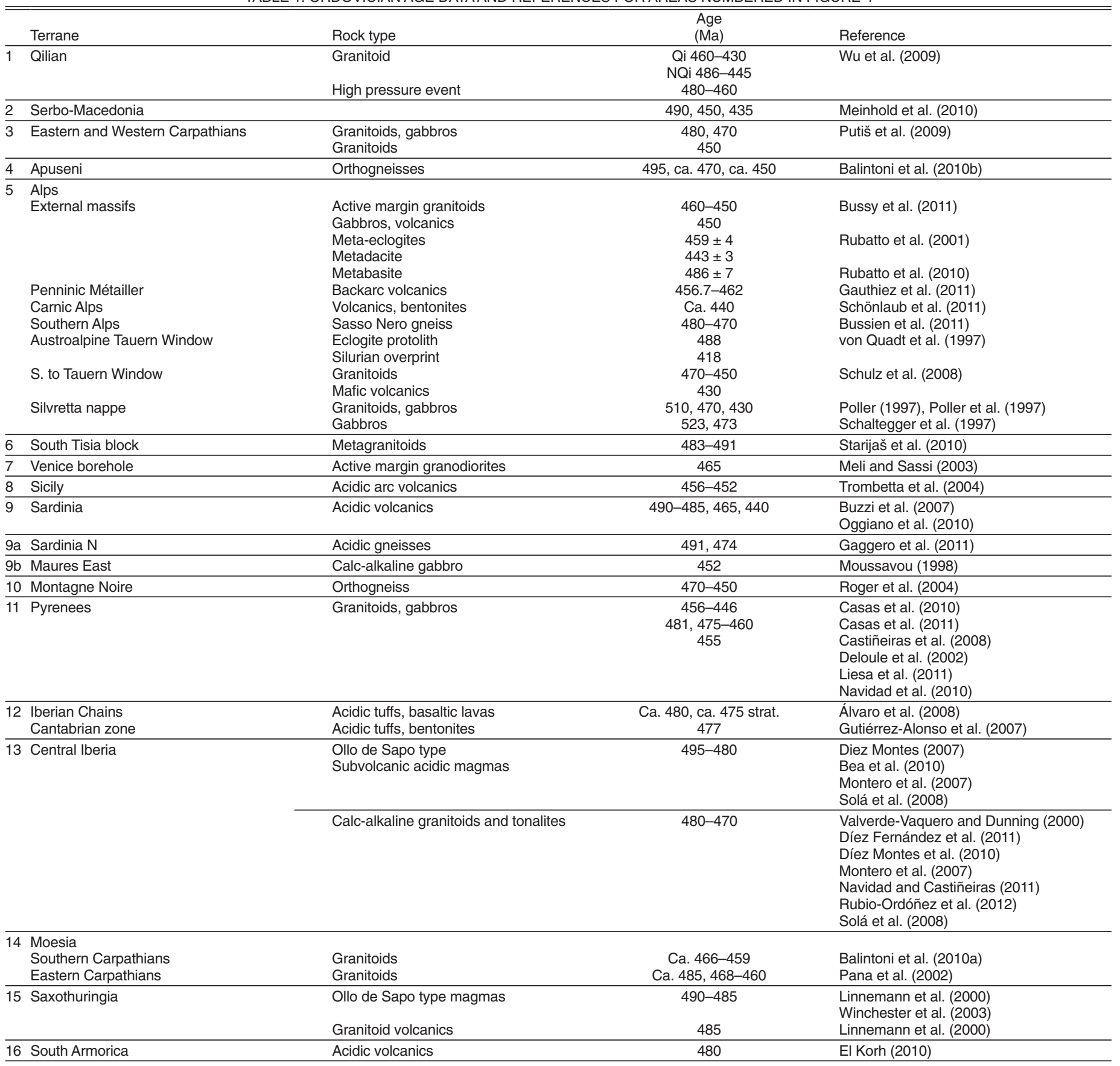

In the Alpine domain, the partial anatectic melting dated by Schaltegger (1993) and Thöny et al. (2008) most likely resulted from a thermal event (450-430 Ma) triggered by crustal extension, confirmed recently for the external domain by new monazite ages (Schulz and von Raumer, 2011). Located along the south Chinese (Gondwana) margin, these areas provide evidence of the transform-type eastern Rheic margin. The emplacement of $450 \mathrm{Ma}$ gabbros along the Gondwana margin, specifically in the external domain (Paquette et al., 1989; Rubatto et al., 2001); the general thermal event in the Austroalpine domain (Schulz et al., 2008; Thöny et al., 2008; Rode et al., 2012); and the extrusion of acidic volcanics in the Noric terrane (Frisch and Neubauer, 1989) are, again, the signature of an extending crust in the Alpine domain. The observation of alkalic metabasites from the Paleozoic Austroalpine Graz (Loeschke and Heinisch, 1993) and Early Silurian, $430 \mathrm{Ma}$ mid-ocean ridge and within-plate basalts from the Austroalpine basement to the south of the Tauern Window (Schulz et al., 2004) are equally attributed to the Late Ordovician-Silurian crustal extension.

Late Ordovician K-bentonite levels from the Carnic Alps (Schönlaub et al., 2011) may have a similar significance. They belong to a tectonically active terrane dominated by calc-alkaline mafic lavas and pyroclastics in the Late Ordovician, Silurian, and Early Devonian. They were located either north or south of the Carnic Alps 
and were separated from the latter by an oceanic realm or at least an open sea of unknown width. However, the K-bentonite horizons in the Carnic Alps range from a few millimeters to a maximum of $2-3 \mathrm{~cm}$ in thickness, indicating that the volcanic source area must have been quite distant (Histon et al., 2007), and integrating the Late Ordovician global magmatic evolution at that time (cf. Bergstrom et al., 2004). These Late Ordovician to Early Silurian magmatic events may still be related to either the eastern Rheic opening or the initial rifting of Paleotethys (Stampfli et al., 2011).

\section{Paleotethys Opening}

The crustal extension along the Gondwana margin during the Late Ordovician to Silurian has been discussed previously (von Raumer and Stampfli, 2008), and it may be worthwhile to readdress this problem in the context of the opening Paleotethys. Its evolution is certainly best constrained in Iran (see Bagheri and Stampfli, 2008, and references therein; Stampfli, 2001), where two rifting events led to its opening. The first event began in the Late Ordovician and was accompanied by a large amount of flood basalts in a subaerial to shallow marine environment; it continued during the Silurian. However, it may have lasted until the Early Devonian, a time of erosion or nondeposition in major parts of Iran, related to the cessation of rifting activity and the inversion of preexisting basins. A new phase in the rifting began in the Middle Devonian with the deposition of evaporites and continental clastics, followed by marine deposits starting in the Givetian. The abandoned Silurian rifts formed rim basins along the future Paleotethys margin, remnants of which are very scarce due to the subsequent subduction. Subsidence curves demonstrate a thermal decay starting in the Middle to Late Devonian; the spreading would have begun in Middle Devonian times, and a general flooding is observed in the Famennian.

Similar subsidence curves (Wilhem, 2010) have also been observed for the south Chinese block, with two rifting pulses and a possible inversion event between them. This scheme can be extended to the Taurus block in Turkey (Moix et al., 2008) and to Central Afghanistan and the southern Lhassa block. Paleotethys remnants are found eastward up to the Far East (Ferrari et al., 2008). In the southern European domain, however, the Paleotethys margin is not well known due to its complete destruction during the collisional events that followed (Variscan and Alpine) or its burial under the major Mesozoic platform in Greece and Italy. Paleotethys Triassic forearc sequences have been described in Crete (Stampfli et al., 2003) and possibly some areas of the Peloponnese, and they may be represented in Italy by the Carboniferous sequences of the Apuane Alps.

In the Alpine domain, tholeiitic and $430 \mathrm{Ma}$ alkaline within-plate basalt-type suites in the pre- and post-Early Ordovician units of the Austroalpine basement can be related to a platetectonic scenario involving terranes in a progressively mature Neoproterozoic to Ordovician active margin and their subsequent incorporation into the Paleotethys passive margin (Schulz et al., 2004).

Potentially older Paleotethyan sequences are found in Sardinia (Gaggero et al., 2012). These contain uppermost Ordovician to Silurian alkali basalts and trachyandesite pillow lavas. Equivalent ages are observed in the southern part of the Central Iberian zone (Late Ordovician and Silurian basic volcanics from Almaden and Sierra de San Pedro and diabase sills; $436 \mathrm{Ma} \mathrm{Sm/Nd}$ isochron age; López-Moro et al., 2007), which are most likely the age equivalents of the Iran suite, comparable to those of the Austroalpine domain. In Spain, Middle Devonian alkaline basanites from the Central Iberian Salamanca region (394 Ma; Gutiérrez-Alonso et al., 2008) were interpreted to represent coeval rifting related to the Rheic Ocean, but these could equally be related to the opening process of the Paleotethys. Additionally, evidence of Middle to Late Devonian rifting is present in the IbericCantabrian-Leonese region (García-Alcalde, 2003), and the potential rift shoulder reliefs were finally transgressed in the Famennian, as in Iran. Deep-water Devonian sediments are found in the Palencia domain. A similar evolution is observed in the Moroccan Meseta (Hoepffner et al., 2005).

The Sardinian, Spanish, and Moroccan sequences represent potential elements of the northern margin of Paleotethys, detached from Gondwana and accompanied by arc-type volcanic activity (e.g., the Frasnian volcanism of Almaden, Sierra de San Pedro), while the Turkish (Taurus), Iranian, and Afghan sequences represent the southern margin and were involved in the Cimmerian collisional events, not the Variscan events (Stampfli and Borel, 2002, 2004; Stampfli and Kozur, 2006). These sequences are generally devoid of any postrift volcanism.

\section{VARISCAN EVOLUTION}

Matte (1986) proposed different time segments for the Variscan evolution in Central Europe, which were used in the plate-tectonic interpretation of the French Massif Central (Faure et al., 2009) and the Bohemian Massif (Schulmann et al., 2009) and correspond to the timing proposed for the Variscan plate-tectonic reconstructions (Stampfli et al., 2011). Since the Early Devonian, various global tectonic events strongly influenced the evolution of the areas that would become the future components of Pangea: (1) the subduction of oceanic crust under Gondwana and Laurussia and the Devonian opening of Paleotethys; (2) the Visean continental collision between the AvaloniaLaurussia and Gondwana-derived continental pieces; and (3) the Pennsylvanian final collision and continuation of the subduction of Paleotethys in the Tethyan area. These three steps will serve to compare the Alpine basements with the European Variscan framework (Fig. 5).

\section{Initiating the Variscan Orogenic Cycle}

During the Early Devonian (Figs. 6A and $6 \mathrm{~B})$, the subduction of the Rheic Ocean is inferred at its northern and southern margins, leading to the opening of Paleotethys at the Gondwana margin. In many Alpine basement areas, polymetamorphic assemblages comparable to those of the contemporaneous European geological framework prevail, testifying to a polyphase metamorphic evolution accompanied by nappe stacking during different periods, depending on the tectonic evolution of specific sectors (Neubauer and Handler, 1999; Stampfli et al., 2002; Guillot and Ménot, 2009). An early peri-Gondwanan phase of subduction and subduction inversion at ca. $380 \mathrm{Ma}$ is characterized by eclogite formation (Stampfli et al., 2002; Liati et al., 2009; von Raumer et al., 2009), indicating that most of the preserved metabasites had been transformed into eclogites. In many places, overprinting by subsequent recrystallization under granulitefacies conditions (Ferrando et al., 2008; Liati et al., 2009; Rubatto et al., 2010) took place during the continental collision at ca. $340 \mathrm{Ma}$. This evolution has been used by Stampfli et al. (2002, 2011) to define a major linear distribution of high-pressure events around 400-380 Ma (Fig. 6B) along the northern active margin of the initial distinct terrane assemblages Ligeria, Armorica, and Galatia (Fig. 7, time slabs 400-370 Ma), which has been compared by Stampfli et al. (2002) with Johnston's (2001) "Alaskan terrane wreck" evolution (cf. Figs. 6B and 6C). In the Austroalpine basement, a high-pressure eclogite- to amphibolites-facies metamorphism has been dated by various methods at 360-300 Ma (Miller and Thöni, 1995; Thöni, 1999; Frey et al., 1999; Schulz et al., 2008; Rode et al., 2012).

Although nappe stacking and the formation of migmatites of former early Paleozoic metasedimentary and magmatic rock assem- 


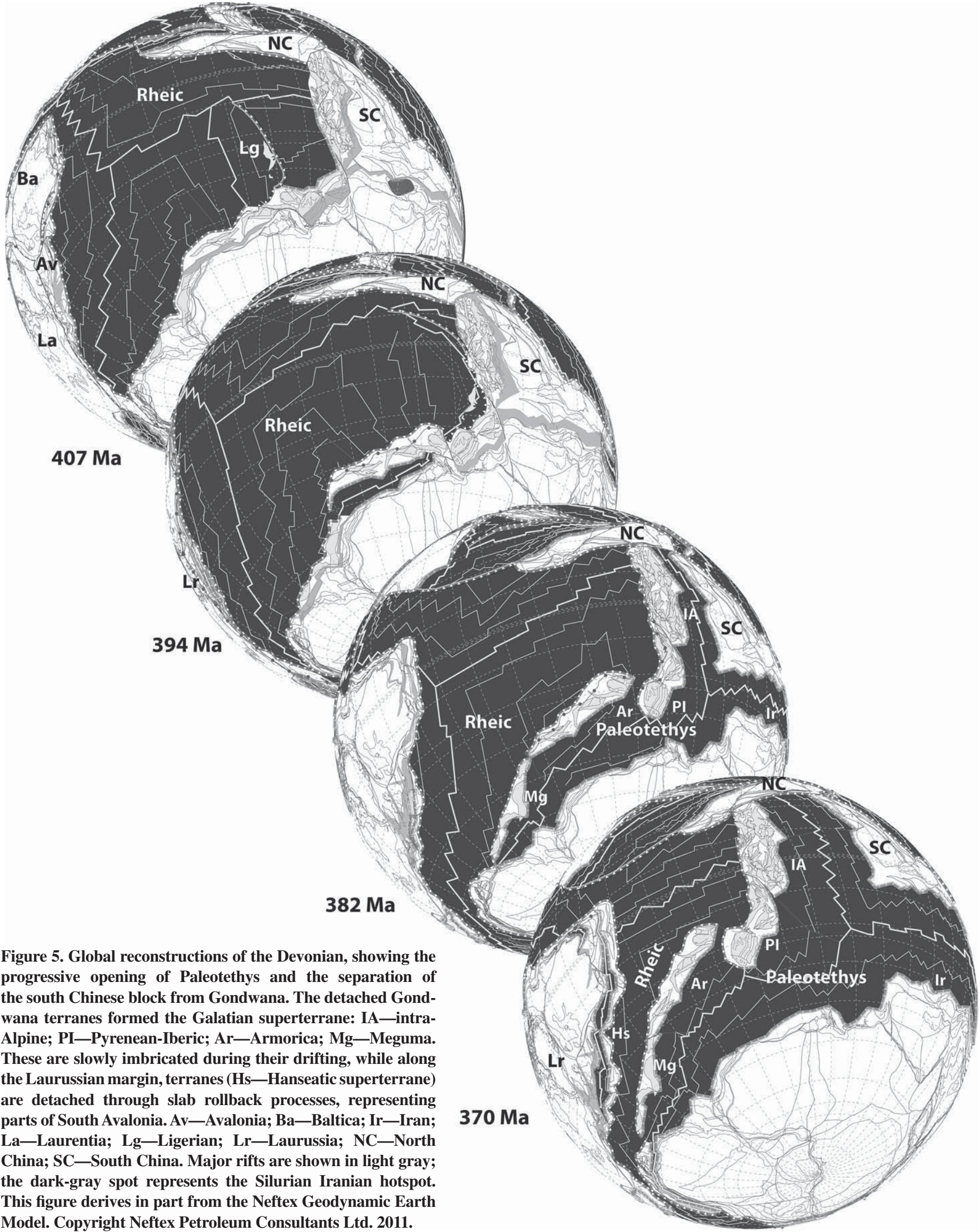
Model. Copyright Neftex Petroleum Consultants Ltd. 2011. 
blages are frequent in the Alpine and extraAlpine basement areas, it is suspected that both meta-eclogites and metasedimentary units survived in the Alpine domain (Aiguilles RougesMont Blanc area-von Raumer and Bussy, 2004; Aar Massif-Schaltegger et al., 2003; Gotthard Massif-Oberli et al., 1994; Biino, 1994, 1995; Argentera-Compagnoni et al., 2010; Lombardo et al., 2011), which may testify to a pre-late Variscan high-pressure metamorphic overprint. Large $(7-8 \mathrm{~cm})$ isolated garnets in mica schists or migmatoid gneisses are reminiscent of kinzigite garnets and may represent relics of an earlier granulitic overprint. Large pseudomorphs of zoisite needles in amphibolites and relics of hercynite-rimmed muscovite pseudomorphs after kyanite in metapelitic rocks indicate that the high-pressure field was traversed before attaining high-temperature conditions. The follow-up of horizons containing plagioclase nodules $(2-10 \mathrm{~cm}$ length) in mica schists could result from the decay of paragonite-phengite assemblages (cf. Proyer, 2003), representing former omphacite-bearing horizons. However, thus far, only meta-eclogites can be safely related to a pre-high-temperature Variscan metamorphic phase.

\section{Time of the Variscan Collision}

Robardet (2003) depicted a general situation of crustal extension for the Gondwana margin in the Devonian, and contemporaneous sedimentary troughs are described for the Alpine domain. The Carnic Alps came under the influence of subsidence during crustal extension (Schönlaub, 1997), and the formation of Visean to Serpukhovian flysch in the Austroalpine domain (Schönlaub and Heinisch, 1993; Neubauer and Handler, 1999) is the fingerprint of the initiating Variscan orogenic events. In the external domain (Ménot and Paquette, 1993; Ménot et al., 1994; Guillot and Ménot, 2009), Devonian volcanic-sedimentary deposits indicate an extensional environment accompanied by granitoid intrusions in the global context of subduction/compression, in which the former, more externally located domain of the Cambrian ultramafic Chamrousse complex has been tectonically emplaced above the more internal metasedimentary series. The first formation of flysch deposits marks the Variscan orogenic events, and the Variscan flyschoid series usually follows an episode of pelagic deposits characterized by condensed red nodular limestones and black radiolarian cherts (lydite). Generally for Late Devonian to Mississippian ages (Tournaisian), this quiescent period corresponds to the drifting of the Variscan terranes before the onset of collisional events.

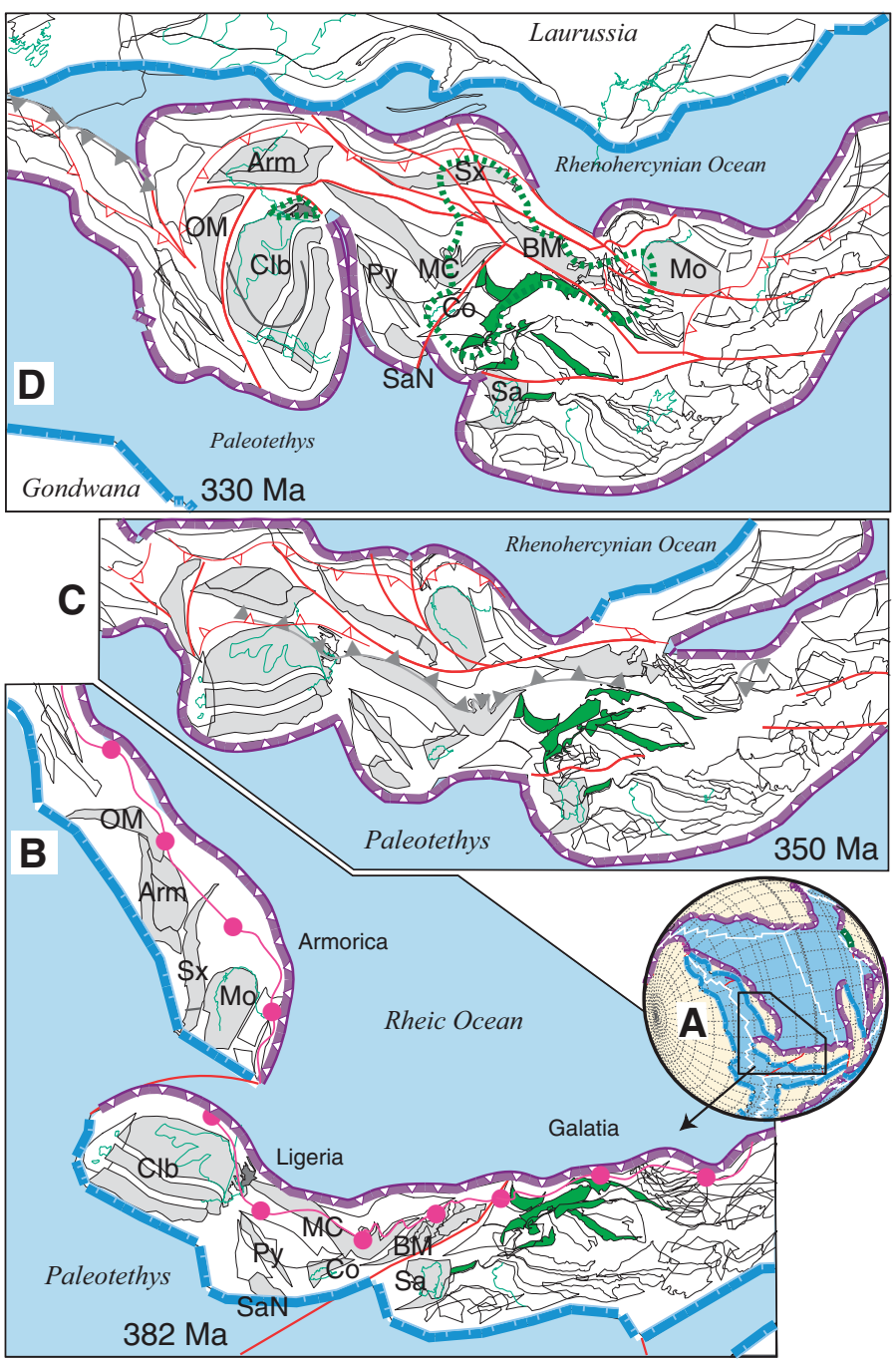

Figure 6. The possible evolution of the future Alpine basement areas in their Variscan framework, from the Devonian to the Pennsylvanian, modified after Stampfli et al. (2011, their fig. 3). Green contours-geographical boundaries. Green domains-the basement constituents of the future Alpine domain. Gray areas indicate often-cited main basement assemblages along the Gondwana margin: Arm-Armorican domain, BM-Bohemian Massif and Barrandian domain, $\mathrm{CIb}$-Iberian assemblages (future allochthonous domain: dark gray), Co-Corsica, Py-Pyrenees, MC-French Central Massif, Mo-Moesian block, OM-Ossa Morena, Sa-Sardinia south, SaN-northern Sardinia, Sx-Saxothuringian domain. (A) Late Devonian (382 Ma) plate-tectonic global reconstruction to demonstrate the localization of the detail of Figure 6B (cf. Fig. 5). (B) Detail from Devonian (382 Ma) plate-tectonic reconstruction showing distinct terrane assemblages separated from Gondwana with Paleotethys in the south and the disappearing Rheic Ocean in the north. The three main terrane assemblages-Armorica, Ligeria, and Galatia-remain separate. Pink line and dots indicate the tectonic limit given by the Early Devonian high-pressure event and observed in many basement areas (cf. Stampfli et al., 2002, 2011). The general situation recalls Johnston's (2001) "Alaskan terrane wreck." (C) Detail from Tournaisian (350 Ma) plate-tectonic reconstruction. The southernmost terranes are dragged along the northern ones through the major relative counterclockwise rotation of Gondwana. (D) Detail from Visean (330 Ma) plate-tectonic reconstruction showing the narrow juxtaposition through large-scale strike slip of formerly separated terranes, indicating the late Variscan oroclinal bending (dark gray line), recently described in the Central Iberian domain (Aerden, 2004; Martínez Catalán, 2011) and the concentration of K-Mg magmatites (green dotted contours) in the Central Iberian and the Central European domains. This figure derives in part from the Neftex Geodynamic Earth Model. Copyright Neftex Petroleum Consultants Ltd. 2011. 


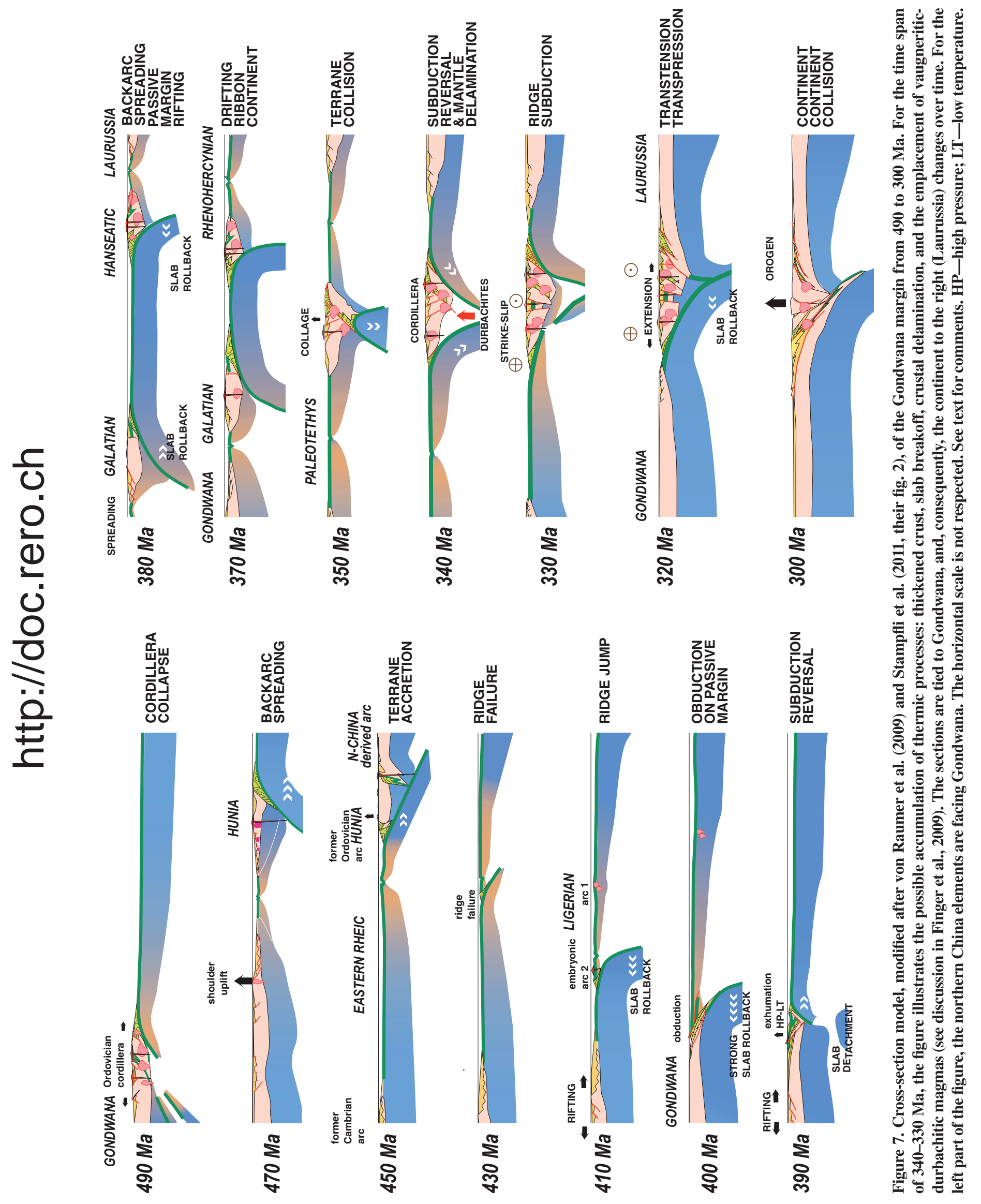


Since the Visean collision, large numbers of Variscan granite bodies have intruded all over the Alpine domain (Bonin et al., 1993). I-type granitoids have been considered to be indicators of a late Paleozoic convergent ocean-continent margin along the southern flank of the Central European Variscan orogen in a late Variscan Andean-type subduction setting (ca. $330 \mathrm{Ma}$; Finger and Steyrer, 1990).

An early granitoid series of ca. 330-340 Ma age is characterized by high $\mathrm{K}$ and $\mathrm{Mg}$ contents (Bussy et al., 2000) with a partial source in the metasomatized lithospheric mantle. Comparable $\mathrm{Mg}-\mathrm{K}$ magmatites are documented in the entire external domain (Debon et al., 1998; von Raumer and Bussy, 2004; von Raumer et al., 2012), including the basement of the Tauern Window (Lammerer, 1986; Veselá et al., 2011).

In the adjacent non-Alpine southern Vosges, the magmatic assemblage of Visean $\mathrm{Mg}-\mathrm{K}$ volcanics and subsequent monzonitic-granodioritic intrusions (e.g., Granite des Crêtes and Granite des Ballons) characterize extensional magmatism in a regional context (Schaltegger et al., 1996). In the nearby Variscan central part of the Vosges, the formation of granulites during the Visean was followed by a heating phase, producing migmatites and late Variscan granitoids (Schaltegger et al., 1999; Schulmann et al., 2002; Tabaud et al., 2012).

Such rocks are also widespread in the main Variscan basement areas north of the Alps and in the Central Iberian basement (e.g., Gallastegui, 2005) below the allochthonous units (Fig. 6D). Schaltegger (1997b) suggested a link with a paleosuture, and von Raumer (1998) argued for a major linear structure involving the entire External Alpine domain and the northern "Moldanubian type" basement areas, based on their Visean spatial distributions. We now believe that these $\mathrm{Mg}$-K-rich rocks are closely related to the Variscan collisional environment (von Raumer et al., 2012). The eo-Variscan high-pressure event (Fig. 6C) most likely documents the collision of the passive Gondwana margin with an exotic arc (see next paragraph); it is disconnected from the Variscan ultrahigh-pressure event (Kotková et al., 2011) related to the Bohemian high-pressure granulites of Visean ages (350-340 Ma; Fig. 7; Kotková et al., 1996; Massonne et al., 2007).

The assumed Visean continental collision (cf. Figs. 6C and 6D) is supported by evidence for an early Visean active margin setting in various localities. Barboni (2011) identified a $350 \mathrm{Ma}$ active margin setting in the northern Armorican domain, and the peralkalic lamproitic plutons at the southern margin of the Balkan orogen (Svoge region, Bulgaria; Buzzi et al., 2010) could correspond to a similar situation. A comparable setting has been proposed for the Central Bohe- mian plutonic complex (Žák et al., 2005). Could the Tournaisian-Visean magmatic events in the southern Vosges and the Black Forest (Schaltegger et al., 1996; Schaltegger, 2000; Hann et al., 2003) correspond to an identical setting? Interestingly, Banzet (1987) has already discussed a comparable setting for the $\mathrm{K}-\mathrm{Mg}$ granitoids of the western Pelvoux domain in the External massifs.

\section{Late Carboniferous-Permian Final Collision and Collapse of the Cordillera}

Current reconstructions (Stampfli et al., 2011; Fig. 3) consider the time since $330 \mathrm{Ma}$ (Fig. 6D) as a period of piling up of basement nappes (Schulz et al., 2008; Guillot et al., 2009) accompanied by large-scale strike slip (Giorgis et al., 1999) and, subsequently, an environment of uplift and exhumation. This general evolution is well known from the basement areas outside the Alps (Black Forest-Schaltegger, 2000; Kalt et al., 2000; French Central Massif-Faure et al., 2009; Central Iberian basement-Martínez Catalán et al., 2007). It led to a widespread high-temperature overprint, resulting in systematic migmatization and the production of polymetamorphic assemblages.

In the Aiguilles Rouges, migmatization (e.g., Genier et al., 2008) occurred at ca. 317 Ma through adiabatic decompression and water-assisted partial melting and was followed by the intrusion of peraluminous melts at 307 Ma (Bussy et al., 2000; Olsen et al., 2000). These melts are observed in all the External massifs; their spectacular aspects have been characterized by Rutishauser (1973). Ferro-potassic granites like the Mont Blanc granite (Bussy, 1990) of ca. 305-295 Ma age, which represent the final part of this general evolution, have been ascribed to crustal thinning and a rising asthenospheric mantle with an emplacement in a pull-apart structure during the late Variscan strike slip (von Raumer and Bussy, 2004). This late Variscan time period is likely to have coincided with the polyphase Variscan deformation history observed in the most western parts of the Aiguilles Rouges (Dobmeier, 1998).

In the Penninic domain, Guillot et al. (2002) identified "distinctive Variscan terranes" through the distribution of magmatic intrusion ages. They showed that Penninic units represent a collage of Variscan terranes before the Alpine reorganization.

During the Pennsylvanian, most of the Alpine basement areas underwent strong exhumation and erosion. In the Salvan-Dorénaz area of the External domain, uplift of $1 \mathrm{~mm} / \mathrm{yr}$ and subsidence of $0.2 \mathrm{~mm} / \mathrm{yr}$ have been recorded in an intracontinental trough setting, active between 308 and $293 \mathrm{Ma}$ and accompanied by magmatic activity during extension (Capuzzo and Bussy, 2000, 2001; Capuzzo et al., 2003; Capuzzo and Wetzel, 2004). The Pennsylvanian molasse-type detritic sediments in the External domain and the eastern Alps almost exclusively contain deposits of Carboniferous age (Capuzzo et al., 2003; Neubauer et al., 2007), indicating that the constituents of the upper crust with preVariscan ages were eroded before the formation of the molasse. Using U-Pb dating of detrital sediments and volcanics, Schaltegger (1997c) revealed the great similarity of PennsylvanianPermian sediments from boreholes located at the limits of the Alpine domain and its northern foreland and discussed the great parallels between the evolution of occurrences in the Aar Massif (Schaltegger and Corfu, 1995) and in the Saxothuringian domain and the French Central Massif. Consequently, a Permian (Fig. 8) reconstruction depicts a basement assemblage in which polyphase metamorphic rocks and migmatites appear in many basement areas, derived from former distinct Devonian plate-tectonic assemblages, telescoped in a rather narrow crosssection model (Fig. 7; cf. Stampfli et al., 2011), and characterized by a comparable pressuretemperature-time evolution in a regional subduction and strike-slip regime.

The radiometric age data from the metamorphic rocks of the Austroalpine basement between 300 and $250 \mathrm{Ma}$ (Thöni, 1999) have long been considered as "Variscan-Alpine mixed" ages. However, in light of the increasing amount of data in this age range, a distinct high-temperature, low-pressure Permian metamorphic event has been postulated (Schuster et al., 2001; Habler and Thöni, 2001; Siegesmund et al., 2007). Supported by electron microprobe Th$\mathrm{U}-\mathrm{Pb}$ monazite age dating, this Permian metamorphic event appears to be spatially related to Permian pegmatites (270-250 Ma). The pegmatites are arranged along a linear zone extending from the southern Oetztal basement (Martell granite; Mair et al., 2007) to the basement south of the Tauern Window (Schulz et al., 2008), and also appearing in the Saualpe and Koralpe basements (Schuster et al., 2001; Habler and Thöni, 2001). A large zone of crustal extension is inferred for this event (Schuster et al., 2001).

During the Pennsylvanian, the internal Ligurian Alps (Cortesogno et al., 1998) were affected by three major volcanic events (Dallagiovanna et al., 2009; LA-ICP-MS dating): calc-alkaline rhyolites $(285.6 \pm 2.6 \mathrm{Ma})$, andesites (with inherited cores yielding ages ca. $276 \mathrm{Ma}$ and older), and voluminous rhyodacites-rhyolites $(272.7 \pm 2.2 \mathrm{Ma})$. Following an amagmatic, sediment-starved time gap of 


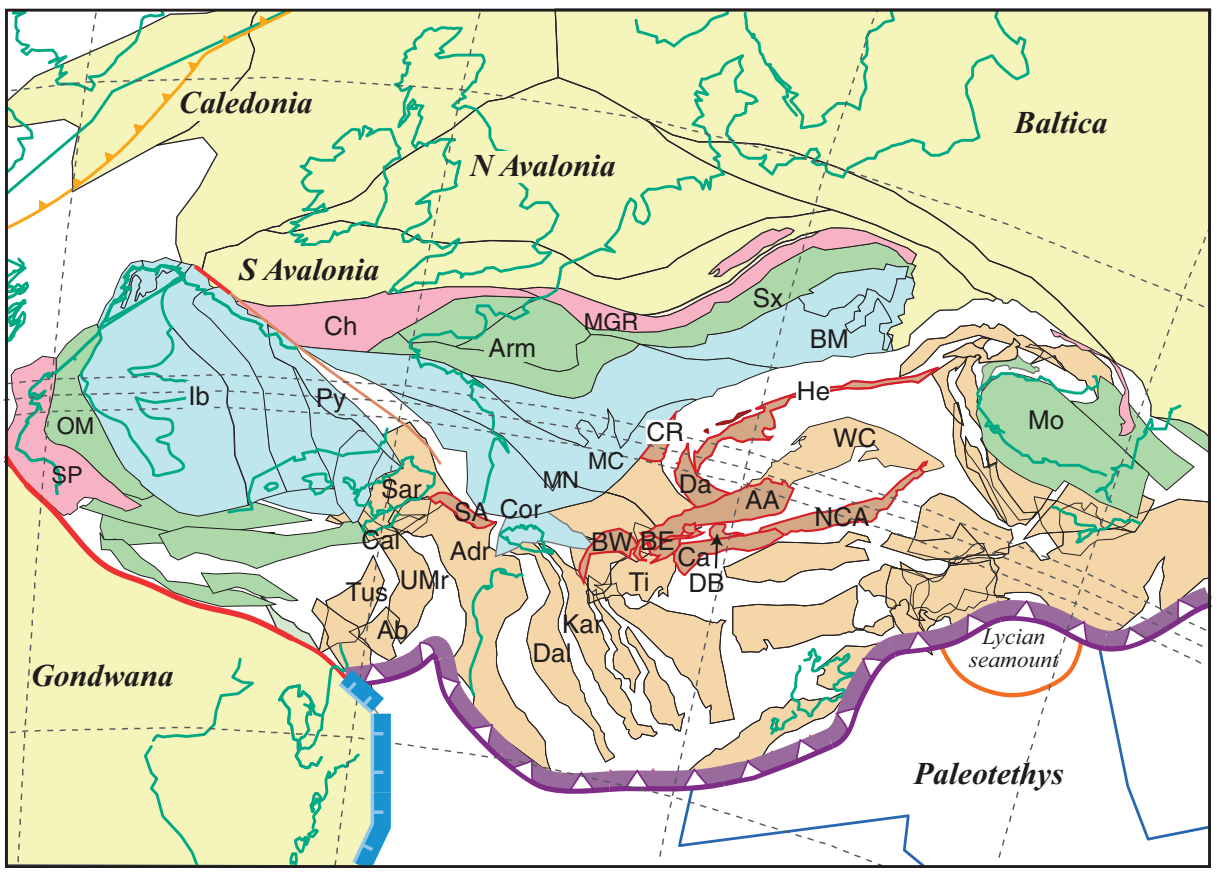

Figure 8. Pre-Mesozoic basement areas of the Alps (brown) in their Variscan framework, represented by its geodynamic units (cf. Fig. 1), in their Permian reconstruction (290 Ma; modified after von Raumer et al., 2011). The Variscan basement units are grouped according to their belonging to one of the Devonian terrane assemblages (Fig. 6). Galatian assemblage (dark brown): Alpine basement: AA-Austroalpine; BE-Briançonnais east; BW-Briançonnais west; Ca-Carnic Alps; CR-Chamrousse; Da-Dauphinois; DB-Dent Blanche; He-Helvetic; NCA-northern Calcareous Alps; SA-southern Alps; (light brown): AbAbruzzi; Adr-Adria; Cal-Calabrian; Dal-Dalmatia; Kar-Karst; Ti-Tiscia; Tus-Tuscan; UMr-Umbria-Marche; Sar-Sardinia; WC_-West Carpathians. Ligerian assemblage (light blue): BM-Bohemian Massifs ligerian; Ib-assemblage of Iberian basements; MCFrench Massif Central; MN-Montagne Noire; Py_Pyrenees. Armorican assemblage (light green): Arm-Armorican Massifs, ligerian; Mo-Moesia assemblage; OM-Ossa Morena; Sx-Saxothuringian. Rhenohercynian assemblage (pink): Ch-Channel Islands; MGRMidgerman Crystalline Rise-Brunovistulicum; SP-South Portuguese zone. Green contours are geographical contours. Orange contour indicates Permian volcanic island. S Avalonia: Beside the Hanseatic terrane mentioned in Figure 5, also, $\mathrm{Sp}, \mathrm{Ch}$, and MGR of the Armorican assemblage belong to South Avalonia. This figure derives in part from the Neftex Geodynamic Earth Model. Copyright Neftex Petroleum Consultants Ltd. 2011.

$\sim 14$ m.y., alkaline volcanic activity is recorded at the top of the sequence by K-alkaline rhyolites dated at $258.5 \pm 2.8 \mathrm{Ma}$. This demonstrates that the Paleotethys subduction continued east of Sardinia during the Permian, supporting the absence of a final collision with Gondwana; in Greece and Turkey, this led to the opening of Early to Middle Triassic oceanic backarc basins (Stampfli and Kozur, 2006).

\section{DISCUSSION}

Pre-Mesozoic basement areas constitute nearly half of the Alpine domain and record its early Paleozoic and Variscan evolution, which resulted from the general plate-tectonic evolution in Central Europe. This evolution began with margin (e.g., Ossa Morena-Sánchez García et al., 2003; NW Iberia-Fernández-Suárez et al., 2000; Rodríguez Alonso et al., 2004; Pereira et al., 2007; Díez Fernández et al., 2011; Saxothuringia-Linnemann et al., 2008; Bohemian Massif-Zulauf et al., 1999; Western Carpathians-Putiš et al., 2009), including the Alpine basement areas, imply a similar early plate-tectonic configuration. This configuration corresponds to a Neoproterozoic suture zone (Linnemann et al., 2008; Murphy et al., 2008; Sánchez Martínez et al., 2009), which is followed by Cambrian-Ordovician magmatic and tectonic evolution along the Gondwana margin, comprising the south Chinese basement areas. Consequently, all the Alpine basements reflect this early peri-Gondwanan magmatic and tectonic evolution, whether they were directly involved, such as the Austroalpine (Oetztal, Silvretta, and south of the Tauern Window) and Penninic basements, or indirectly imported by the Variscan Nappes, as believed of the External basements.

In the Ordovician, the configuration at the Gondwana margin changed considerably during the opening of the western branch of the Rheic Ocean. Behind the future Avalonian terranes, a rift basin opened along the more western Gondwana margin behind the subducting Iapetus-Tornquist Ocean, receiving the detrital sediments of what is generally referred to as the "Armorican quartzite," the paleogeographic scenario illustrated in Figure 4.

From the Early Ordovician onward, several magmatic pulses and scenarios dominated the general evolution in the European basement areas, including the Alpine domains, and consisted of the stepwise evolution from a volcanic arc to a continental arc with the subsequent collision and opening of backarc basins. This rather long period of time represents one of the major magmatic events in the global framework (Pankhurst et al., 1998; Bergstrom et al., 2004; Condie et al., 2009) and corresponds to a cordillera-type evolution along the Gondwana margin. The Iberian blocks and the easternmost sector, such as the Alpine and Tethyan blocks, characterize this early Paleozoic evolution (Stampfli et al., 2011) as a long-lasting crustal extension and arc development along the western Gondwana margin. Diachronous opening of the Rheic Ocean along the African margin is proposed here, where the easternmost margin was close to a transform margin along the south Chinese segment of Gondwana, with a complicated history that was accompanied by several pulses of Ordovician magmatic evolution. The general active margin setting during the earliest Cambrian (Fig. 1; Stampfli et al., 2011) affected almost the entire Gondwana 
margin. The subsequent transcurrent migration of an island-arc structure along the eastern margin (Stampfli et al., 2011) may have suppressed the formation of deep crustal extension during the following periods. However, how many of the elements involved in this scenario can be attributed to former constituents of the Chinese or Gondwana-derived blocks? When compared with the contemporaneous evolution in the Austroalpine units described previously, the parallels with the Chinese Qilian evolution are interesting (Wu et al., 2009).

The identification of certain rock types from the western Gondwana margin in the eastern continuation remains problematic. The early Ollo de Sapo-type granitoids that intruded at 495-480 Ma along the western Gondwana margin had counterparts in more eastern areas before the general transcurrent displacement of an arc modified this original scenario. The observation of blue quartz phenocrysts in contemporaneous granitoids, such as the Austroalpine Mönchalp granite ("older orthogneisses"), in contact with an Ordovician gabbro, is attributed to a volcanic arc setting (Poller et al., 1997) and indicates a comparable formation and contact under lower-crustal conditions. Similarly, Schulz et al. (2004) differentiated an older Austroalpine basement with 484 Ma Oetztal felsic intrusions (Bernhard et al., 1996) before the Ordovician 470 Ma gabbros intruded. Cambrian-Ordovician granitoids in the Penninic domain (Vanoise-Siviez Mischabel: 520-480 Ma; Guillot et al., 2002), which represent an older granitoid cycle with alkaline metarhyolites and metagranites, could correspond to the Ollo de Sapo granitoids before the subsequent platetectonic Ordovician evolution at the eastern margin produced a new configuration. Guillot et al. (2002) discussed the separation of "distinctive Variscan terranes" assembled in the Penninic domain. An example of this early volcanic series in the non-Alpine domain may be the pre-Sardic phase volcanics observed in the southern part of Sardinia (491 Ma; Oggiano et al., 2010).

Parallels to an Ordovician polyphase magmatic evolution, discussed previously, come from the eastern prolongation of the Alpine domain, the Carpathian Apuseni Mountains, where Balintoni et al. (2010b) dated Ordovician granitoid gneisses belonging to distinct age groups (see Table 1).

In contrast, the magmatic evolution from the Middle Ordovician to the Silurian was mainly restricted to the eastern Gondwana margin (Fig. 4; Table 1), characterizing the complex plate-tectonic evolution of basement areas like the Alps and the adjacent Tethyan areas. The Variscan basement areas in the eastern Alps have historically been subdivided into a pre-
Ordovician older basement and an Ordovician phyllite series: the low-grade metamorphic "classical Paleozoic" Ordovician to Devonian series. When considering the intrusion of Late Ordovician volcanics above the Sardic unconformity (Dack, 2009; Oggiano et al., 2010) and the inversion of older rifts to produce the Armorican quartzite, the opening of the eastern branch of the Rheic Ocean corresponds to the scenario of a collision of a Qilian-type arc with the Gondwana active margin (arc-arc collision), followed by a general collapse of the cordillera.

Interestingly, Early Silurian ages have been observed in the Central Iberian allochthonous Cabo Ortegal and Ordenes high-pressure domains (Fernández-Suárez et al., 2002, 2007), and the question of their geological meaning arises when they are compared with the global evolution of the eastern Gondwana margin. Were they part of the Caledonian-Acadian orogenic evolution characterizing the Laurussian margin or did they belong to the Gondwana margin (compare discussion), as discussed by Stampfli et al. (2011)? In this context, one should avoid inferring a common evolution between the Avalonian-Acadian alpine-type orogenic evolution at the border of Baltica and a Gondwana-related Cambrian-Ordovician evolution, with the latter representing a Gondwanan early Paleozoic cordillera.

\section{Variscan Evolution}

In the well-known Variscan reconstructions of Central Europe (e.g., Matte, 1986; Franke 1989), the significance of the Alpine domains has been neglected, although "it is a matter of fact, that the Alpine basement displays a nearly continuous outcrop of the Variscan orogen" (Schaltegger, 1997a, p. 261). The Devonian subduction phase (ca. $380 \mathrm{Ma}$ ) and the accompanying high-pressure phase described earlier herein served as a limit between terrane assemblages (Fig. 6B) and is viewed as a collision zone of the Gondwanan passive margin with an exotic arc, which may have been reworked by the Variscan ultrahigh-pressure event at ca. 350-340 Ma (Fig. 7). The specific Variscan convergent double subduction scenario allows the transportation of tectonic elements from either side of the arc into great depth, with slab detachment enabling them to rise to higher levels.

In a Visean reconstruction (Fig. 6C), one type of major lineament is thought to include the External Alpine massifs, with their corresponding counterparts exposed in the Tauern Window (before the Alpine tectonics), and the non-Alpine Variscan neighboring basement areas of Moldanubian type located immediately to the north (von Raumer, 1998). The presence of Visean
$\mathrm{Mg}-\mathrm{K}$-rich magmatites suggests that their distribution is related to the Variscan subduction and collision events, with the rising lithospheric mantle and slab breakoff leading, through distinct processes (cf. Henk et al., 2000), to a general thermal rise and triggering the intrusion of the many vaugnerite-durbachite bodies (Fig. 7). These concurrent processes could have generated areas of high heat flux between the opposed subduction zones (Fig. 7, 340-330 Ma), producing a type of late Variscan hotspot structure, as depicted in Figure 6.

Evidently, a direct consequence of the Devonian subduction/collision processes in the various Variscan basement terranes (Fig. 6B) was the creation of major suture zones between different terranes, as derived from the Late Devonian-Mississippian reconstructions. Traces of the former Variscan subducting plate scenario are observed in the External domain (see previous) and may also be present in the basements of the Penninic domain (e.g., the Adula, Tambo, and Suretta nappes) and in the Austroalpine Oetztal nappe, at the southern border of the Tauern Window, and probably in the Tonale nappe basement of the Ulten-Tal. In the latter location, Martin et al. (2004) and Braga et al. (2007) have described and dated rock assemblages reminiscent of a well-known high-pressure evolution in the Aiguilles-Rouges Massif of the External domain (von Raumer et al., 2009).

The lateral displacement and juxtaposition of basement areas at different times since the Pennsylvanian make it difficult to determine whether their original locations were in the Bohemian Massif area or along the Gondwana margin. Interestingly, Finger et al. (2007) described the double line of $\mathrm{Mg}-\mathrm{K}$-rich magmatic bodies in the Bohemian Massif as a consequence of juxtaposition (see also Schulmann et al., 2009), whereas Tabaud et al. (2012) invoked a difference of radiogenic heat production for the Vosges. Hann et al. (2003) discussed the tectonic significance of Visean magmatic bodies in the southern Black Forest area, and Gallastegui (2005) depicted the locations of the different vaugnerite localities in northwestern Spain at the boundary of the major Variscan thrust sheet. As a consequence, it is not surprising that a tectonic zonation can be observed in the External Alpine domain as well (Guillot et al., 2009), because the basement areas at the northern border of Gondwana were located along a major strike-slip system (Stampfli et al., 2002) and because during the subduction of Paleotethys under Laurussia and following the collision, continental strike-slip zones affected all the basement areas (Stampfli et al., 2011).

As a consequence of Matte's (2001) global model of the Variscan domain, different papers have discussed the significance of a supposed 
late Variscan large-scale strike-slip zone aligning the different basement areas of CorsicaSardinia, with the External domains of the Alps (Corsini and Rolland, 2009; Guillot et al., 2009; Rossi et al., 2009) as satellites. However, their lithostratigraphies and metamorphic zoning should be discussed first in the context of the preceding plate-tectonic scenarios (e.g., Stampfli, 2012) before their involvement in the Pennsylvanian-Permian strike-slip system. This late Variscan plate-tectonic scenario was related to the continuing subduction of Paleotethys under Laurussia combined with slab rollback, producing different geometries along the Laurussia-Avalonia border zone. As a consequence, in the Permian reconstruction (Fig. 8; $290 \mathrm{Ma}$ ), many Galatian geodynamic units followed a nearly identical Pennsylvanian-Permian geological evolution to that of the Alpine geodynamic units. If this Permian reconstruction is compared carefully with Figure 1, the reader may discover specific geodynamic units at different places in the Permian that may currently be hidden under a much younger sedimentary cover. Although these hidden areas are strongly transformed by Alpine tectonics, they must be considered at their original (e.g., Pennsylvanian) locations when comparing their original geological basement evolution. The Permian final Pangea assemblage gradually underwent Mesozoic and Tertiary rearrangement (Stampfli and Hochard, 2009), leading to the construction of the Alpine mountain chain.

\section{CONCLUSION}

The main basement units of the Alpine domain have shared a geological evolution with the adjacent Central European basement areas since the Neoproterozoic. The main steps of this evolution are interpreted in the light of new plate-tectonic reconstructions from the Cambrian onward (Stampfli et al., 2011; Stampfli, 2012). They are controlled by the initial locations of the domains along the northern margin of Gondwana and are characterized by several magmatic pulses in a cordillera-type setting during the Cambrian-Ordovician time period (Fig. 4; Table 1; cf. Rubio- Ordóñez et al., 2012). The reconstructions allow the consideration of possible parallels between the magmatic and sedimentary evolutionary trends observed during the early Paleozoic along the entire Gondwana margin and the shift of the subsequent magmatic events to the more eastern part of the Gondwana margin during the Late Ordovician-Silurian. They also provide a better understanding of the Variscan orogenic evolution by identifying early Variscan highpressure relics and Visean K-Mg magmatites as evidence for a major suture zone related to the preexisting subduction of an early Variscan crust in the lower-plate position. If the External massifs represent the southern limit of durbachiticvaugneritic rocks, including the limit of the Variscan continental collision provokes the question of which domain of this Variscan subduction system is represented in the more southern Alpine nappes, such as the Adula nappe, which should, then, represent the exhumed parts of the former subducted equivalents and possibly parts of former Variscan back-folded domains during the Variscan orogenic events.

The main difficulty in developing an adequate understanding of the pre-Alpine basement evolution is in the succession of overprinting events, such as the ongoing northward subduction of the oceanic domains under Laurussia during the Permian, the occurrence of global strike-slip movements in adjacent areas at the same time, and the multiphase Alpine orogeny. These issues have led to the currently confusing puzzle of Gondwana-derived crustal pieces. Field work must continue and refined analytical approaches must be developed to fill the gaps. Many eclogite bodies must be redated more precisely to better understand their paths through the crust, and more data are necessary to better discriminate between Gondwana and the Chinaderived geodynamic units that constitute the giant Alpine puzzle.

\section{ACKNOWLEDGMENTS}

Active research in the Alpine domain has benefited from the participation of many working groups, and without their knowledge, the progress made in this area over the years could not have been synthesized in this study. Encouraging suggestions by Laura Gaggero (Genova) helped considerably during the final formulation of this paper. The critical perspectives of Ricardo Arenas (Madrid) and José-Ramon Martínez Catalán (Salamanca) reminded us continually not to lose sight of the large-scale overview. We thank Jana Kotková (Brno) for stimulating suggestions concerning the high-pressure evolution of granulites, and Daniel Bernoulli (Zürich) and Fritz Finger (Salzburg) provided interesting information about the occurrence of Ordovician granitoids in the Venetia and Tizia areas, respectively. A general acknowledgment goes to the Swiss Fonds National, which funded our research for many years. We enjoyed the constructive remarks and careful reviews provided by Bob Hatcher (Knoxville) and an anonymous reviewer and extend our appreciation to the assistant editor. This contribution is based in part upon, or is derivative of, the geodynamic reconstructions and associated PaleoDyn and Recon databases that constitute a component of the Neftex Geodynamic Earth Model. We appreciated the permission granted by Neftex Petroleum Consultants Ltd. to publish these results, and we gratefully acknowledge the patient help of the editorial team.

\section{REFERENCES CITED}

Abrecht, J., Biino, G., and Schaltegger, U., 1995, Building the European continent: Late Proterozoic-early Palaeozoic accretion in the central Alps of Switzerland: Terra Nova, v. 5, p. 105.
Aerden, D.G.A.M., 2004, Correlating deformation in Variscan NW-Iberia using porphyroblasts; implications for the Ibero-Armorican Arc: Journal of Structural Geology, v. 26, p. 177-196, doi:10.1016/S0191-8141 (03)00070-1.

Álvaro, J.J., Ezzouhairi, H., Ribeiro, M.L., Ramos, J.F. and Solá, R., 2008, Early Ordovician volcanism in the Iberian Chains (NE Spain) and its influence on the preservation of shell concentrations: Bulletin de la Société Géologique de France, v. 179, p. 569-581, doi:10.2113/gssgfbull 179.6.569.

Arnold, A., 1970, Die Gesteine der Region Nalps-Curnera im nordöstlichen Gotthardmassiv, ihre Metamorphose und ihre Kalksilikat-Einschlüsse: Beiträge zur Geologischen Karte der Schweiz Neue Folge, v. 138, p. 1-12.

Bagheri, S., and Stampfli, G.M., 2008, The Anarak, Jandaq and Posht-e-Badam metamorphic complexes in central Iran: New geological data, relationships and tectonic implications: Tectonophysics, v. 451, p. 123-155, doi: 10.1016/j.tecto.2007.11.047.

Balintoni, I., and Balica, C., 2012, Carpathian peri-Gondwanan terranes in the East Carpathians (Romania): A testimony of an Ordovician, North-African orogeny: Gondwana Research doi:10.1016/j.gr.2012.07.013 (in press).

Balintoni, I., Balica, C., Ducea, M.N., Hann, H.P., and Şabliovschi, V., 2010a, The anatomy of a Gondwanan terrane: The Neoproterozoic-Ordovician basement of the pre-Alpine Sebeș-Lotru composite terrane (South Carpathians, Romania): Gondwana Research, v. 17, p. 561-572, doi:10.1016/j.gr.2009.08.003.

Balintoni, I., Balica, C., Ducea, M.N., Zaharia, L., Chen, F., Clivet, M., Hann, H.P., Li, L.-Q., and Ghergari, L., 2010b, Late Cambrian-Ordovician northeastern Gondwanan terranes in the basement of the Apuseni Mountains, Romania: Journal of the Geological Society of London, v. 167, p. 1-15, doi:10.1144 /0016-76492009-156.

Banzet, G., 1987, Interaction croûte-manteaux et genese du plutonisme subalcalin du Haut Dauphiné occidental (Massifs cristallins externs): Vaugnérites, durbachites et granitoides magnésio-potassiques: Géologie Alpine, v. 63 , p. $95-117$.

Barboni, M., 2011, Construction Mechanisms and Thermal Evolution of Upper Crustal Intrusions: The SaintJean-Du Doigt Bimodal Intrusion (Brittany, France) [Ph.D. thesis]: Lausanne, Switzerland, Université of Lausanne, $286 \mathrm{p}$

Bea, F., Montero, P., Talavera, C., Abu Anbar, M., Scarrow, J.H., Molina, J.F., and Moreno, J.A., 2010, The paleogeographic position of Central Iberia in Gondwana during the Ordovician: Evidence from zircon chronology and Nd isotopes: Terra Nova, v. 22, p. 341-346, doi:10.1111/j.1365-3121.2010.00957.x.

Bergstrom, S.M., Huff, W.D., Saltzman, M.R., Kolata, D.R., and Leslie, S.A., 2004, The greatest volcanic ash falls in the Phanerozoic: Trans-Atlantic relations of the Ordovician Millbrig and Kinnekulle K-bentonites: The Sedimentary Record, v. 2, no. 4, p. 4-8.

Bernhard, F., Klötzli, U.S., Thöni, M., and Hoinkes, G., 1996, Age, origin and geodynamic significance of a polymetamorphic felsic intrusion in the Oetztal crystalline basement, Tirol, Austria: Mineralogy and Petrology, v. 58, p. 171-196, doi:10.1007/BF01172095.

Biino, G., 1994, The pre-Late Ordovician metamorphic evolution of the Gotthard-Tavetsch massifs (central Alps): From lawsonite to kyanite eclogite to granulite retrogression: Schweizerische Mineralogische und Petrographische Mitteilungen, v. 74, p. 87-104.

Biino, G., 1995, Pre-Variscan evolution of the eclogitized mafic rocks from the Helvetic basement of the central Alps: European Journal of Mineralogy, v. 7, p. 57-70.

Bonin, B. (coord.), Brändlein, P., Bussy, F., Desmons, J., Eggenberger, U., Finger, F., Graf, K., Marro, Ch., Mercolli, I., Oberhänsli, R., Ploquin, A., von Quadt, A., von Raumer, J., Schaltegger, U., Steyrer, H.P., Visona, D., and Vivier, G., 1993, Late Variscan magmatic evolution, in von Raumer, J., and Neubauer, F., eds., The Pre-Mesozoic Geology in the Alps: Heidelberg, Germany, Springer, p. 171-201.

Braga, R., Massonne, H.-J., and Morten, L., 2007, An early metamorphic stage for the Variscan Ulten zone 
gneiss (NE Italy): Evidence from mineral inclusions in kyanite: Mineralogical Magazine, v. 71, p. 691-702. doi:10.1180/minmag.2007.071.6.691.

Buschmann, B., Nasdala, L., Jonas, P., Linnemann, U., and Gehmlich, M., 2001, SHRIMP U-Pb dating of tuf derived and detrital zircons from Cadomian marginal basin fragments (Neoproterozoic) in the northeastern Saxothuringian zone (Germany): Neues Jahrbuch für Geologie und Paläontologie Monatshefte, v. 2001, p. 321-342.

Bussien, D., Bussy, F., Magna, T., and Masson, H., 2011, Timing of Palaeozoic magmatism in the Maggia and Sambucco nappes and paleogeographic implications (Central Lepontine Alps): Swiss Journal of Geosciences, v. 104, p. 1-29, doi:10.1007/s00015 -010-0049-6.

Bussy, F., 1990, Pétrogenèse des enclaves micro-grenues associées aux granitoïdes calco-alcalins: Exemple des massifs varisque du Mont-Blanc (Alpes occidentales) et miocène du Monte Capanne (Ile d'Elbe, Italie): Mémoires de Géologie, Lausanne, v. 7, p. 1-309.

Bussy, F., Hernandez, J., and von Raumer, J., 2000, Bimodal magmatism as a consequence of the post-collisional re adjustment of the thickened Variscan continental lithosphere (Aiguilles Rouges/Mont-Blanc Massifs, western Alps): Transactions of the Royal Society of Edinburgh-Earth Sciences, v. 91, p. 221-233, doi:10.1017 /S0263593300007392.

Bussy, F., Péronnet, V., Ulianov, A., Epard, J.L., and von Raumer, J., 2011, Ordovician magmatism in the external French Alps: Witness of a peri-Gondwanan active continental margin, in Gutiérrez-Marco, J.C., Rábano, I., and García-Bellido, D., eds., The Ordovician of the World: Madrid, Instituto Geológico y Minero de España, Cuadernos del Museo Geominero, v. 14, p. 75-82.

Buzzi, L., Funedda, A., Gaggero, L., Oggiano, G., and Tiepolo, M., 2007, U-Pb zircon dating (LA-ICP-MS) of the Ordovician felsic volcanism through the Variscan Units in Sardinia (Italy): Geophysical Research Abstracts, v. 9,03789.

Buzzi, L., Gaggero, L., Grozdanov, L., Yanev, S., and Slejko, F., 2010, High-Mg potassic rocks in the Balkan seg ment of the Variscan belt (Bulgaria): Implications for the genesis of orogenic lamproite magmas: Geological Magazine, v. 147, p. 434-450, doi:10.1017 /S0016756809990550.

Capuzzo, N., and Bussy, F., 2000, High-precision dating and origin of synsedimentary volcanism in the late Carboniferous Salvan-Dorénaz basin (Aiguilles-Rouges Massif, western Alps): Schweizerische Mineralogische und Petrographische Mitteilungen, v. 80, p. 147-167.

Capuzzo, N., and Bussy, F., 2001, Syn-sedimentary volcanism in the late Carboniferous Salvan-Dorénaz basin (western Alps): Natura Bresciana Annali Museo Civico Scienze Naturali Brescia Monografia, v. 25, p. 203-211.

Capuzzo, N., and Wetzel, A., 2004, Facies and basin architecture of the late Carboniferous Salvan-Dorénaz continental basin (western Alps, Switzerland/France) Sedimentology, v. 51, p. 675-697, doi:10.1111/j.1365 $-3091.2004 .00642 . x$

Capuzzo, N., Handler, R., Neubauer, F., and Wetzel, A., 2003, Post-collisional rapid exhumation and erosion during continental sedimentation: The example of the late-Variscan Salvan-Dorenaz basin (western Alps): International Journal of Earth Sciences, v. 92, p. 364 379, doi:10.1007/s00531-003-0332-0.

Casas, J.P., Castiñeiras, P., Navidad, M., Liesa, M., and Carreras, J., 2010, New insights into the Late Ordovician magmatism in the Eastern Pyrenees: U-Pb SHRIMP zircon data from the Canigó Massif: Gondwana Research, v. 17, p. 317-324, doi:10.1016/j.gr.2009.10.006.

Casas, J.P., Castiñeiras, P., Navidad, M., Liesa, M., Martinez, J.F., Carreras, J., Reche, J., Iriondo, A., Aleinikoff, J. Cirés, J., and Dietsch, C., 2011, Ordovician magmatism in NE Iberia, in Gutiérrez-Marco, J.C., Rábano, I., and García-Bellido, D., eds., The Ordovician of the World: Madrid, Instituto Geológico y Minero de España, Cuadernos del Museo Geominero, v. 14, p. 95-100.

Castiñeiras, P., Navidad, M., Liesa, M., Carreras, J., and Casas, J.M., 2008, U-Pb zircon ages (SHRIMP) for Cadomian and Early Ordovician magmatism in the Eastern Pyrenees: New insights into the pre-Variscan evolution of the northern Gondwana margin: Tectonophysics, v. 461, p. 228-239, doi:10.1016/j.tecto.2008 .04 .005 .

Chiaradia, M., 1993, The scheelite-skarn of Salanfe (Valais, Switzerland): Schweizerische Mineralogische und Petrographische Mitteilungen, v. 73, p. 41-51.

Chlupaĉ, I., Havliceek, V., Kriz, J., Kukal, J., and Storch, P., 1998, Palaeozoic of the Barrandian (Cambrian to Devonian): Prague, Czech Geological Survey, 183 p.

Compagnoni, R., Ferrando, S., Lombardo, B., Radulesco, N., and Rubatto, D., 2010, Paleo-European crust of the Italian western Alps: Geological history of the Argentera Massif and comparison with Mont BlancAiguilles Rouges and Maures-Tanneron Massifs, in Beltrando, M., Peccerillo, A., Mattei, M., Conticelli, S., and Doglioni, C., eds., The Geology of Italy: Journal of the Virtual Explorer, v. 36, paper 4, doi:10.3809 /jvirtex.2009.00228

Condie, K.C., Belousova, E., Griffin, W.L., and Sircombe, K.N., 2009, Granitoid events in space and time: Constraints from igneous and detrital zircon age spectra: Gondwana Research, v. 15, p. 228-242, doi:10.1016 /j.gr.2008.06.001

Corsini, M., and Rolland, Y., 2009, Late evolution of the southern European Variscan belt: Exhumation of the lower crust in a context of oblique convergence: Comptes Rendus de l'Académie des Sciences, Geoscience, v. 341, p. 214-223, doi:10.1016/j.crte.2008.12.002.

Cortesogno, L., Cassinis, G., Dallagiovanna, G., Gaggero, L., Oggiano, G., Ronchi, A., Seno, S., and Vanossi, M., 1998, The Variscan post-collisional volcanism in late Carboniferous-Permian sequences of Ligurian Alps, southern Alps and Sardinia (Italy): A synthesis: Lithos, v. 45, p. 305-328, doi:10.1016/S0024-4937 (98)00037-1.

Dack, A.V., 2009, Internal Structure and Geochronology of the Gerrei Unit in the Flumendosa Area, Variscan External Nappe Zone, Sardinia, Italy [Master's thesis]: Boise, Idaho, Boise State University, $100 \mathrm{p}$.

Dallagiovanna, G., Gaggero, L., Maino, M., Seno, S., and Tiepolo, M., 2009, U-Pb zircon ages for post-Variscan volcanism in the Ligurian Alps (northern Italy): Journal of the Geological Society of London, v. 166, p. 101-114, doi:10.1144/0016-76492008-027.

Debon, F., Guerrot, C., Ménot, R.P., Vivier, G., and Cochérie, A., 1998, Late Variscan granites of the Belledonne Massif (French western Alps): An early Visean magnesian plutonism: Schweizerische Mineralogische und Petrographische Mitteilungen, v. 78, p. 69-87.

Deloule, E., Alexandrov, P., Cheilletz, A., Laumonier, B., and Barbey, P., 2002, In situ U-Pb zircon ages for Early Ordovician magmatism in the eastern Pyrenees, France: The Canigou orthogneisses: International Journal of Earth Sciences, v. 91, p. 398-405, doi:10.1007 /s00531-001-0232-0.

Desor, E., 1865, Sur la disposition des massifs cristallins des Alpes ou zones d'affleurement: Bulletin de la Société Géologique de France, v. 2, p. 360-364.

Díez Fernández, R., Castiñeiras, P., and Gómez Barreiro, J., 2012, Age constraints on Lower Paleozoic convection system: Magmatic events in the NW Iberian Gondwana margin: Gondwana Research, v. 21, p. 1066-1079, doi:10.1016/j.gr.2011.07.028

Diez Montes, A., 2007, La geología del dominio "Ollo de Sapo" en las comarcas de Sanabria y Terra do Bolo: Serie Nova Terra, v. 34, p. 494.

Díez Montes, A., Martínez Catalán, J.R., and Bellido Mulas, F., 2010, Role of the Ollo de Sapo massive felsic volcanism of NW Iberia in the Early Ordovician dynamics of northern Gondwana: Gondwana Research, v. 17, p. 363-376, doi:10.1016/j.gr.2009.09.001.

Dobmeier, C., 1998, Variscan $P-T$ deformation paths from the southwestern Aiguilles Rouges Massif (External massif, western Alps) and their implication for its tectonic evolution: Geologische Rundschau, v. 87, p. 107 123, doi: $10.1007 / \mathrm{s} 005310050193$.

Dobmeier, C., Pfeifer, H.R., and Von Raumer, J.F., 1999 The newly defined "Greenstone Unit" of the AiguillesRouges massif (western Alps); remnant of an early Palaeozoic oceanic island-arc: Schweizerische Mineralogische und Petrographische Mitteilungen, v. 79, p. $263-276$.
Drost, K., Gerdes, A., Jeffries, T., Linnemann, U., and Storey, C., 2010, Provenance of Neoproterozoic and early Palaeozoic siliciclastic rocks of the Teplá-Barrandian unit (Bohemian Massif): Evidence from U-Pb detrital zircon ages: Gondwana Research, v. 19, p. 213-231, doi: 10.1016/j.gr.2010.05.003.

Ebel, J.G., 1808, Ueber den Bau der Erde in dem AlpenGebirge: Zürich, Orell Fuessli und Companie, Volume I, $408 \mathrm{p}$

Ehling, B.-C., 1993, Geologie und Geochemie der Scheelitskarnlagerstätte von Delitzsch (NW-Sachsen) [Ph.D. thesis]: Freiberg, Germany, Bergakademie, 119 p.

Eichhorn, R., Schärer, U., and Höll, R., 1995, Age and evolution of scheelite-hosting rocks in the Felbertal deposit (eastern Alps): U-Pb geochronology of zircon and titanite: Contributions to Mineralogy and Petrology, v. 119, p. 377-386, doi:10.1007/BF00286936.

Eichhorn, R., Höll, R., Loth, G., and Kennedy, A., 1999 , Implications of U-Pb SHRIMP zircon data on the age and evolution of the Felbertal tungsten deposit (Tauern Window, Austria): International Journal of Earth Sciences, v. 88, p. 496-512, doi:10.1007/s005310050281.

Eichhorn, R., Loth, G., and Kennedy, A., 2001, Unravelling the pre-Variscan evolution of the Habach terrane (Tauern Window, Austria) by U-Pb SHRIMP zircon data: Contributions to Mineralogy and Petrology, v. 142, p. 147-162, doi:10.1007/s004100100284.

Einaudi, M.T., Meinert, L.O., and Newberry, R.J., 1981 Skarn deposit: Economic Geologist, 75th Anniversary Volume, p. 317-391.

El Korh, A., Schmidt, S. Th., Ballèvre, M., Oulianoff, A., and Bruguier, O., 2012, Discovery of an albite gneiss from the Ile de Groix Armorican Massif, France): Geochemistry and LA-ICP-MS U-Pb geochronology of ist Ordovician protolith: International Journal of Earth Sciences (Geologische Rundschau), v. 101, p. 1169-1190.

Escher, A., Hunziker, J., Masson, H., Sartori, M., and Steck, A., 1997, Geologic framework and structural evolution of the Western Swiss Alps, in Pfiffner, O.A., Lehner, P., Heitzmann, P., Müller, S., and Steck, A., eds., Deep Structure of Switzerland. Results from the National Research Program 20 (NRP20): Basel, Birkhäuser, p. $205-221$.

Faure, M. Lardeux, J.M., and Ledru, P., 2009, A review of the pre-Permian geology of the Variscan French Massif Central: Comptes Rendus de l'Académie des Sciences, Geoscience, v. 341, p. 202-213, doi:10.1016 lj.crte.2008.12.001

Fernández-Suárez, J., Gutíerrez-Alonso, G., Jenner, G.A and Tubrett, M.N., 2000, New ideas on the Proterozoicearly Palaeozoic evolution of NW Iberia: Insights from $\mathrm{U}-\mathrm{Pb}$ detrital zircon ages: Precambrian Research, v. 102, p. 185-206, doi:10.1016/S0301-9268(00)00065-6.

Fernández-Suárez, J., Corfu, F., Arenas, R., Marcos, A., Martínez Catalán, J.R., Díaz García, F., Abati, J., and Fernández, J., 2002, U-Pb evidence for a polyorogenic evolution of the HP-HT units of the NW Iberian Massif: Contributions to Mineralogy and Petrology, v. 143 , p. 236-253, doi:10.1007/s00410-001-0337-2.

Fernández-Suárez, J., Arenas, R., Abati, J., Martínez Catalán, J.R., Whitehouse, M.J., and Jeffries, T.E., 2007, $\mathrm{U}-\mathrm{Pb}$ chronometry of polymetamorphic high-pressure granulites: An example from the allochthonous terranes of the NW Iberian Variscan belt, in Hatcher, R.D., Jr. Carlson, M.P., McBride, J.H., and Martínez Catalán, J.R., eds., 4-D Framework of Continental Crust: Geological Society of America Memoir 200, p. 469-488.

Ferrando, S., Lombardo, B., and Compagnoni, R., 2008, Metamorphic history of HP mafic granulites from the Gesso-Stura terrain (Argentera Massif, western Alps, Italy): European Journal of Mineralogy, v. 20, p. 777 790, doi:10.1127/0935-1221/2008/0020-1891.

Ferrari, O.M., Hochard, C., and Stampfli, G.M., 2008, An alternative plate tectonic model for the Palaeozoic-early Mesozoic Palaeotethyan evolution of Southeast Asia (northern Thailand-Burma: Tectonophysics, v. 451, p. 346-365, doi:10.1016/j.tecto.2007.11.065.

Finger, F., and Steyrer, H.P., 1990, I-type granitoids as indicators of a late Paleozoic convergent ocean/continen margin along the southern flank of the Central European Variscan orogen: Geology, v. 18, p. 1207-1210, doi: 10.1130/0091-7613(1990)018<1207:ITGAIO>2.3.CO;2. 
Finger, F., Gerdes, A., Janušek, V., René, M., and Riegler, G., 2007, Resolving the Variscan evolution of the Moldanubian sector of the Bohemian Massif: The significance of the Bavarian and the Moravo-Moldanubian tectonometamorphic phases: Journal of Geosciences, v. 52, p. 9-28, doi:10.3190/jgeosci.005.

Finger, F., Gerdes, A., René, M., and Riegler, G., 2009, The Saxo-Danubian Granite Belt: Magmatic response to postcollisional delamination of mantle lithosphere below the southwestern sector of the Bohemian Massif (Variscan orogen): Geologica Carpathica, v. 60, p. 205-212, doi:10.2478/v10096-009-0014-3.

Franke, W., 1989, Tectonostratigraphic units in the Variscan belt of central Europe, in Dallmeyer, R.D., ed., Terranes in the Circum-Atlantic Paleozoic Orogens: Geological Society of America Special Paper 230, p. 67-90.

Franz, L., and Romer, R.L., 2007, Caledonian high-pressure metamorphism in the Strona-Ceneri zone (southern Alps of southern Switzerland and northern Italy): Swiss Journal of Geosciences, v. 100, p. 457-467, doi: 10.1007/s00015-007-1232-2.

Frey, M., Desmons, J., and Neubauer, F., eds., 1999, The New Metamorphic Map of the Alps: Schweizerische Mineralogische und Petrographische Mitteilungen, v. 79 , Zürich, Stäubli Verlag, $230 \mathrm{p}$.

Frisch, W., and Neubauer, F., 1989, Pre-Alpine terranes and tectonic zoning in the eastern Alps, in Dallmeyer, R.D., ed., Terranes in the Circum-Atlantic Paleozoic Orogens: Geological Society of America Special Paper 230, p. 91-114.

Gaggero, L., Cortesogno, L., and Bertrand, J. M., 2004, The pre-Namurian basement of the Ligurian Alps: A review of the lithostratigraphy, pre-Alpine metamorphic evolution, and regional comparisons: Periodico di Mineralogia Special Issue 2: A Showcase of the Italian Research in Metamorphic Petrology: Periodico di Mineralogia, v. 73, p. 85-96.

Gaggero, L., Oggiano, G., and Casini, L., 2011, U-Pb radiometric dating of the Leptyno-amphibolite complex in the Asinara Island (Sardinia): Unravelling a long-lived Gondwanan basement: EPITOME, v. 4, p. 182-183.

Gaggero, L., Oggiano, G., Funedda, A., and Buzzi, L., 2012, Rifting and arc-related early Paleozoic volcanism along the north Gondwana margin: Geochemical and geological evidence from Sardinia (Italy): The Journal of Geology, v. 120, p. 273-292, doi:10.1086/664776.

Gallastegui, G., 2005, Petrología del Macizo Granodiorítico de Bayo-Vigo (Provincia de Pontevedra, España): Serie Nova Terra, v. 26: La Coruña, Spain, Laboratorio Xeolóxico de Laxe, Ediciós O Castro, 414 p

García-Alcalde, J.L., coord., 2003, Devonian, in Gibbons, W., and Moreno, T., eds., The Geology of Spain: London, p. 67-90.

Gauthiez, L., Bussy, F., Ulianov, A., Gouffon, Y., and Sartori, M., 2011, Ordovician mafic magmatism in the Métailler Formation of the Mont-Fort nappe (Middle Penninic domain, western Alps)—Geodynamic implications [abs.]: Abstract Volume, 9th Swiss Geoscience Meeting: Zürich, p. 110-111.

Genier, F., Bussy, F., Epard, J.L., and Baumgartner, L., 2008, Water-assisted migmatization of metagraywackes in a Variscan shear zone, Aiguilles-Rouges Massif, western Alps: Lithos, v. 102, p. 575-597, doi:10.1016 j.lithos.2007.07.024

Giorgis, D., Thélin, P., Stampfli, G.M., and Bussy, F., 1999, The Mont-Mort metapelites: Variscan metamorphism and geodynamic context (Briançonnais basement, western Alps: Switzerland): Schweizerische Mineralogische und Petrographische Mitteilungen, v. 79, p. 381-398.

Guillot, F., Schaltegger, U., Bertrand, J.M., Deloule, E., and Baudin, T., 2002, Zircon U-Pb geochronology of Ordovician magmatism in the polycyclic Ruitor Massif (Internal W Alps): International Journal of Earth Sciences, v. 91, p. 964-978, doi:10.1007/s00531-002-0280-0.

Guillot, St., and Ménot, R.-P., 2009, Paleozoic evolution of the External Crystalline Massifs of the western Alps: Comptes Rendus de l'Académie des Sciences, Geoscience, v. 341, p. 253-265, doi:10.1016/j.crte 2008.11.010.

Guillot, St., di Paola, S., Ménot, R.-P., Ledru, P., Spalla, M.I., Gosso, G., and Schwartz, St., 2009, Suture zones and importance of strike-slip faulting for Variscan geo- dynamic reconstructions of the External Crystalline Massifs of the western Alps: Bulletin de la Société Géologique de France, v. 180, p. 483-500, doi:10.2113 /gssgfbull.180.6.483.

Gutiérrez-Alonso, G., Fernández-Suárez, J., GutiérrezMarco, J.C., Corfu, F., Murphy, J.B., and Suárez, M. 2007, U-Pb depositional age for the upper Barrios Formation (Armorican quartzite facies) in the Cantabrian zone of Iberia: Implications for stratigraphic correlation and paleogeography, in Linnemann, U., Nance, R.D., Kraft, P., and Zulauf, G., eds., The Evolution of the Rheic Ocean: From Avalonian-Cadomian Active Margin to Alleghenian-Variscan Collision: Geological Society of America Special Paper 423, p. 287-296.

Gutiérrez-Alonso, G., Murphy, J.B., Fernández-Suárez, J., and Hamilton, M.A., 2008, Rifting along the northern Gondwana margin and the evolution of the Rheic Ocean: A Devonian age for the El Castillo volcanic rocks (Salamanca, Central Iberian zone): Tectonophysics, v. 461, p. 157-165, doi:10.1016/j.tecto.2008.01.013.

Habler, G., and Thöni, M., 2001, Preservation of PermoTriassic low-pressure assemblages in the Cretaceous high-pressure metamorphic Saualpe crystalline basement (eastern Alps, Austria): Journal of Metamorphic Geology, v. 19, p. 679-697, doi:10.1046/j.0263 -4929.2001.00338.x.

Handy, M.R., Schmid, D.M., Bousquet, R., Kissling, E., and Bernoulli, D., 2010, Reconciling plate-tectonic reconstructions of Alpine Tethys with the geological-geophysical record of spreading and subduction in the Alps: Earth-Science Reviews, v. 102, p. 121-158, doi:10.1016/j.earscirev.2010.06.002

Hann, H.P., Chen, F., Zedler, H., Frisch, W., and Loeschke, J., 2003, The Rand Granite in the southern Schwarzwald and its geodynamic significance in the Variscan belt of SW Germany: International Journal of Earth Sciences, v. 92, p. 821-842, doi:10.1007/s00531-003-0361-8.

Henk, A., von Blankenburg, F., Finger, F., Schalteger, U., and Zulauf, G., 2000, Syn-convergent high-temperature metamorphism and magmatism in the Variscides: A discussion of potential heat sources, in Franke, W., Haak, V., and Tanner, D., eds., Orogenic Processes: Quantification and Modelling in the Variscan Belt: Geological Society of London Special Publication 179, p. 387-399.

Histon, K., Klein, P., Schönlaub, H.P., and Huff, W.D., 2007, Lower Paleozoic K-bentonites from the Carnic Alps, Austria: Mitteilungen der Österreichischen Geologischen Gesellschaft, v. 100, p. 26-42.

Hochard, C., 2008, GIS and Geodatabases Application to Global Scale Plate Tectonics Modelling [Ph.D. thesis]: Lausanne, Switzerland, University of Lausanne, $164 \mathrm{p}$.

Hoepffner, Ch., Soulaimani, A., and Piqué, A., 2005, The Moroccan Hercynides: Journal of African Earth Sciences, v. 43, p. 144-165, doi:10.1016/j.jafrearsci.2005 .09.002.

Hunziker, J.C., Desmons, J., and Hurford, A.J., 1992, ThirtyTwo Years of Geochronological Work in the Central and western Alps: A Review on Seven Maps: Mémoires de Géologie (Lausanne) 13, $60 \mathrm{p}$

Johannes, W., and Holtz, F., 1996, Petrogenesis and Experimental Petrology of Granitic Rocks: Berlin, Germany, Springer, $335 \mathrm{p}$.

Johnston, S.T., 2001, The Great Alaskan terrane wreck: Reconciliation of paleomagnetic and geological data in the northern Cordillera: Earth and Planetary Science Letters, v. 193, p. 259-272, doi:10.1016/S0012 -821X(01)00516-7.

Kalt, A., Altherr, R., and Hanel, M., 2000, The Variscan basement of the Schwarzwald: Beiheft zum European Journal of Mineralogy, v. 12, p. 1-43.

Kotková, J., Kröner, A., Todt, W., and Fiala, J., 1996, Zircon dating of North Bohemian granulites, Czech Republic: Further evidence for the lower Carboniferous high-pressure event in the Bohemian Massif: Geologische Rundschau, v. 85, p. 154-161, doi:10.1007/s005310050064.

Kotková, J., O'Brien, P.J., and Ziemann, M.A., 2011, Diamond and coesite discovered in Saxony-type granulite: Solution to the Variscan garnet peridotite enigma: Geology, v. 39, p. 667-670, doi:10.1130/G31971.1.

Lammerer, B., 1986, Das Autochthon im westlichen Tauernfenster: Jahrbuch der Geologischen Bundesanstalt Wien, v. 129, p. 51-67.
Liati, A., Gebauer, D., and Fanning, C.M., 2009, Geochronological evolution of HP metamorphic rocks of the Adula nappe, central Alps, in pre-Alpine and Alpine subduction cycles: Journal of the Geological Society of London, v. 166, p. 797-810, doi:10.1144/0016 $-76492008-033$

Liebetrau, V., and Nägler, T., 1994, Geochronologische und geochemische Diskussion der sogenannten "flüelagranitischen Assoziation" des Silvrettakristallins (Graubünden/ Schweiz): Schweizerische Mineralogische und Petrographische Mitteilungen, v. 74, p. 265-268.

Liesa, M., Carreras, J., Castiñeiras, P., Casas, J.M., Navidad, M., and Vilà, M., 2011, U-Pb zircon age of Ordovician magmatism in the Albera Massif (Eastern Pyrenees): Geologica Acta, v. 9, p. 93-101.

Linnemann, U., Gehmlich, M., Tichomirowa, M., Buschmann, B., Nasdala, L., Jonas, P., Lützner, H., and Bombach, K., 2000, From Cadomian subduction to early Paleozoic rifting: The evolution of Saxo-Thuringia at the margin of Gondwana in the light of single zircon geochronology and basin development (central European Variscides, Germany), in Franke, W., Haak, V., Oncken, O., and Tanner, D., eds., Orogenic Processes: Quantification and Modelling in the Variscan Belt: Geological Society of London Special Publication 179, p. 131-153, doi:10.1144/GSL.SP.2000.179.01.10.

Linnemann, U., Gerdes, A., Drost, K., and Buschmann, B., 2007, The continuum between Cadomian orogenesis and opening of the Rheic Ocean: Constraints from LA-ICP-MS U-Pb zircon dating and analysis of platetectonic setting (Saxo-Thuringian zone, northeastern Bohemian Massif, Germany), in Linnemann, U. Nance, D., Kraft, P., and Zulauf, G., eds., The Evolution of the Rheic Ocean: From Avalonian-Cadomian Active Margin to Alleghenian-Variscan Collision: Geological Society of America Special Paper 423, p. 61-96.

Linnemann, U., Pereira, F., Jeffries, T.E., Drost, K., and Gerdes, A., 2008, The Cadomian orogeny and the opening of the Rheic Ocean: The diacrony of geotectonic processes constrained by LA-ICP-MS U-Pb zircon dating (Ossa-Morena and Saxo-Thuringian zones, Iberian and Bohemian Massifs): Tectonophysics, v. 461, p. $21-43$.

Loeschke, J., and Heinisch, H., 1993, Palaeozoic volcanism of the eastern Alps and its palaeotectonic significance, in von Raumer, J., and Neubauer, F., eds., The pre-Mesozoic Geology in the Alps: Berlin, Germany, Springer, p. 441-455.

Lombardo, B., Compagnoni, R., Ferrando, S., Radulesco, N., and Rolland, Y., 2011, Variscan geology of the Argentera Massif, western Alps, and comparison with the Maures-Tanneron Massifs (France): Annales du Musée de Histoire Naturelle Nice, v. XXVI, p. 139-163.

López-Moro, F.J., Murciego, A., and López-Plaza, M., 2007. Silurian/Ordovician asymmetrical sill-like bodies from La Codosera syncline, W Spain: A case of tholeiitic partial melts emplaced in a single magma pulse an derived from a metasomatized mantle source: Lithos, v. 96, p. 567-590, doi:10.1016/j.lithos.2006.12.006.

Loth, G., Eichhorn, R., Höll, R., Kennedy, A., Schauder, P., and Söllner, F., 2001, Cambro-Ordovician age of a metagabbro from the Wildschönau ophiolite complex, Greywacke Supergroup (eastern Alps, Austria): A U-Pb SHRIMP study: European Journal of Mineralogy, v. 13, p. 57-66, doi:10.1127/0935-1221/01/0013-0057.

Mair, V., Nocker, C., and Tropper, P., 2007, Das OrtlerCampo Kristallin in Südtirol: Mitteilungen der Österreichischen Mineralogischen Gesellschaft, v. 153, p. 219-240.

Martin, S., Tumiati, S., and Laurenzi, M., 2004, The Ulten Unit: Late Paleozoic metamorphic evolution of a subduction mélange, in 32nd International Geological Congress, Atti di Convegno Internazionale: Florence, Italy, Societá Cooperativa Tipografica, Padova, Italy, v. 1, abstract 89-3, p. 434.

Martínez Catalán, J.R., 2011, Are the oroclines of the Variscan belt related to late Variscan strike-slip tectonics: Terra Nova, v. 23, p. 241-247, doi:10.1111/j.1365 $-3121.2011 .01005 . \mathrm{x}$.

Martínez Catalán, J.R., and 13 others, 2007, Space and time in the tectonic evolution of the northwestern Iberian Massif: Implications for the Variscan belt, in Hatcher 
Jr., R.D., Carlson, M.P., McBride, J.H., and Martínez Catalán, J.R., eds., 4-D Framework of Continental Crust: Geological Society of America Memoir 200, p. $400-423$.

Massonne, H.-J., Kennedy, A., Nasdala, L., and Theye, T., 2007, Dating of zircon and monazite from diamondiferous quartzofeldspathic rocks of the Saxonian Erzgebirge hints at burial and exhumation velocities: Mineralogical Magazine, v. 71, p. 407-425, doi:10.1180 /minmag.2007.071.4.407.

Matte, P., 1986, Tectonics and plate tectonics model for the Variscan belt of Europe: Tectonophysics, v. 126, p. 329-374, doi:10.1016/0040-1951(86)90237-4.

Matte, P., 2001, The Variscan collage and orogeny (480$290 \mathrm{Ma}$ ) and the tectonic definition of the Armorica microplate; a review: Terra Nova, v. 13, p. 122-128, doi:10.1046/j.1365-3121.2001.00327.x.

Meinhold, G., Kostopoulos, D., Frei, D., Himmerkus, F., and Reischmann, T., 2010, U-Pb LA-SF-ICP-MS zircon geochronology of the Serbo-Macedonian Massif, Greece: Palaeotectonic constraints for Gondwana derived terranes in the Eastern Mediterranean: International Journal of Earth Sciences, v. 99, p. 813-832, doi:10.1007/s00531-009-0425-5.

Meinhold, G., Morton, A.C., and Avigad, D., 2012, New insights into peri-Gondwana paleogeography and the Gondwana super-fan system from detrital zircon U-Pb ages: Gondwana Research, doi:10.1016/j.gr.2012 .05 .003 (in press).

Meli, S., and Sassi, R., 2003, The Venice Granodiorite: Constraints on the Caledonian and Variscan events in the Alpine domain: Rendiconti Academia Lincei Scienze Fisiche et Naturali, s. 9, v. 14, p. 179-204.

Ménot, R.-P., and Paquette, J.-L., 1993, Geodynamic significance of basic and bimodal magmatism in the External domain, in von Raumer, J.F., and Neubauer, F., eds. The Pre-Mesozoic Geology in the Alps: Heidelberg, Germany, Springer-Verlag, p. 241-254.

Ménot, R.-P., Peucat, J.J., Scarenzi, D., and Piboule, M., 1988 , 496 My age of plagiogranites in the Chamrousse ophiolite complex (External Crystalline Massifs in the French Alps): Evidence of a Lower Paleozoic oceanization: Earth and Planetary Science Letters, v. 88, p. 82-92.

Ménot, R.-P., von Raumer, J.F., Bogdanof, S., and Vivier, G., 1994, Variscan basement of the western Alps: The External Crystalline Massifs, in Keppie, J.D., ed. Pre-Mesozoic Geology in France and Related Areas: Heidelberg, Germany, Springer-Verlag, p. 458-466.

Miller, C., and Thöni, M., 1995, Origin of eclogites from the Austroalpine Ötztal basement (Tirol, Austria): Geochemistry and Sm-Nd vs. Rb-Sr isotope systematics: Chemical Geology, v. 122, p. 199-225, doi:10.1016 /0009-2541(95)00033-I.

Moix, P., Beccaletto, L., Kozur, H., Hochard, C., Rosselet, F., and Stampfli, G.M., 2008, A new classification of the Turkish terranes and sutures and its implication for the paleotectonic history of the region: Tectonophysics, v. 451, p. 7-39, doi:10.1016/j.tecto.2007.11.044

Montero, C., Bea, F., González-Lodeiro, F., Talavera, C., and Whitehouse, M.J., 2007, Zircon ages of the metavolcanic rocks and metagranites of the Ollo de Sapo domain in central Spain: Implications for the Neoproterozoic to early Palaeozoic evolution of Iberia: Geological Magazine, v. 144, p. 963-976, doi:10.1017 /S0016756807003858.

Moussavou, M., 1998, Contribution à l'Histoire Thermotectonique Varisque du Massif des Maures par la Typologie du Zircon et la Géochronologie U/Pb sur Minéraux Accessoires [Ph.D. thesis]: Montpellier, France, Université de Montpellier 2, $187 \mathrm{p}$

Müller, A., van den Kerkhof, A.M., Behr, H.-J., Kronz, A., and Koch-Müller, M., 2009, The evolution of late Hercynian granites and rhyolites documented by quartz-A review: Earth and Environmental Science Transactions of the Royal Society of Edinburgh, v. 100 p. 185-204, doi:10.1017/S1755691009016144.

Müller, B., Klötzli, U., Schaltegger, U., and Flisch, M. 1996, Early Cambrian oceanic plagiogranite in the Silvretta nappe, eastern Alps: Geochemical, zircon U-Pb and $\mathrm{Rb}-\mathrm{Sr}$ data from garnet-hornblende-plagioclase gneisses: Geologische Rundschau, v. 85, p. 822-831, doi:10.1007/BF02440113.
Murphy, J.B., Gutiérrez-Alonso, G., Nance, R.D., FernandezSuárez, J., Keppie, J.D., Quesada, C., Strachan, R.A., and Dostal, J., 2006, Origin of the Rheic Ocean: Rifting along a Neoproterozoic suture?: Geology, v. 34, p. 325-328, doi:10.1130/G22068.1.

Murphy, J.B., Gutiérrez-Alonso, G., Fernández-Suárez, J., and Braid, J.A., 2008, Probing crustal and mantle lithosphere origins through Ordovician volcanic rocks along the Iberian passive margin of Gondwana: Tectonophysics, v. 461, p. 166-180, doi:10.1016/j.tecto.2008.03.013.

Nance, R.D., and Murphy, J.B., 1994, Contrasting basement isotopic signatures and the palinspastic restoration of peripheral orogens: Example from the Neoproterozoic Avalonian-Cadomian belt: Geology, v. 22, p. 617-620, doi:10.1130/0091-7613(1994)022<0617: CBISAT $>2.3 . \mathrm{CO} ; 2$.

Nance, R.D., Gutiérrez-Alonso, G., Keppie, J.D., Linnemann, U., Murphy, J.B., Quesada, C., Strachan, R.A., and Woodcock, N.H., 2010, Evolution of the Rheic Ocean: Gondwana Research, v. 17, p. 194-222, doi:10.1016 /j.gr.2009.08.001.

Navidad, M., and Castiñeiras, P., 2011, Early Ordovician magmatism in the northern Central Iberian zone (Iberian Massif): New U-Pb (SHRIMP) ages and isotopic $\mathrm{Sr}-\mathrm{Nd}$ data, in Gutiérrez-Marco, J.C., Rábano, I., and GarcíaBellido, D., eds., The Ordovician of the World: Madrid, Instituto Geológico y Minero de España, Cuadernos del Museo Geominero, v. 14, p. 391-398.

Navidad, M., Castiñeiras, P., Casas, J.M., Liesa, M., Fernández Suárez, J., Barnolas, A., Carreras, J., and Gil-Peña, I., 2010, Geochemical characterization and isotopic age of Caradocian magmatism in the northeastern Iberian Peninsula: Insights into the Late Ordovician evolution of the northern Gondwana margin: Gondwana Research, v. 17, p. 325-337, doi:10.1016/j.gr.2009.11.013.

Neubauer, F., 2002, Evolution of late Neoproterozoic to early Paleozoic tectonic elements in central and southeast European Alpine mountain belts: Review and synthesis: Tectonophysics, v. 352, p. 87-103, doi:10.1016 /S0040-1951(02)00190-7.

Neubauer, F., and Frisch, W., 1993, The Austro-Alpine metamorphic basement east of the Tauern window, in von Raumer, J.F., and Neubauer, F., eds., The Pre-Mesozoic Geology in the Alps: Heidelberg, Springer, p. 515-536.

Neubauer, F., and Handler, R., 1999, Variscan orogeny in the eastern Alps and Bohemian Massif: How do these units correlate: Mitteilungen der Österreichischen Geologischen Gesellschaft, v. 92 , p. 35-59.

Neubauer, F., Frisch, W., and Hensen, B.T., 2002, Early Palaeozoic tectonothermal events in basement complexes of the Eastern Greywacke zone (eastern Alps): Evidence from U-Pb zircon data: International Journal of Earth Sciences, v. 91, p. 775-786, doi:10.1007 Is00531-001-0254-7.

Neubauer, F., Friedl, G., Genser, J., Handler, R., Mader, D., and Schneider, D., 2007, Origin and tectonic evolution of the eastern Alps deduced from dating of detrital white mica: A review: Austrian Journal of Earth Sciences, v. 100, p. 8-23.

Niggli, E., 1960, Mineralzonen der alpinen Metamorphose in den Alpen: 21st International Geological Congress: Copenhagen, v. 13, p. 132-138.

Oberhänsli, R., ed., 2004, Explanatory notes to the map: Metamorphic structure of the Alps: Mitteilungen der Oesterreichischen Mineralogischen Gesellschaft, v. 149, p. 113-226.

Oberli, F., Meier, M., and Biino, G., 1994, Time constraints on the pre-Variscan magmatic/metamorphic evolution of the Gotthard and Tavetsch units derived from singlezircon U-Pb results: Schweizerische Mineralogische und Petrographische Mitteilungen, v. 74, p. 483-488.

Oggiano, G., Gaggero, L., Funedda, A., Buzzi, L., and Tiepolo, M., 2010, Multiple early Paleozoic volcanic events at the northern Gondwana margin: $\mathrm{U}-\mathrm{Pb}$ age evidence from the southern Variscan branch (Sardinia, Italy): Gondwana Research, v. 17, p. 44-58, doi: 10.1016/j.gr.2009.06.001

Olsen, S.N., Johnson, C.M., Beard, B.L., and Baumgartner, L.P., 2000, New U-Pb zircon data and constraints on the age and mode of migmatization in the Aar Massif, central Alps: European Journal of Mineralogy, v. 12, p. $1245-1260$.
Pană, D., Balintoni, I., Heaman, L., and Creaser, R., 2002, The U-Pb and Sm-Nd dating of the main lithotectonic assemblages of the Eastern Carpathians, Romania: Geologica Carpathica, v. 53, p. 177-180.

Pankhurst, R.J., Rapela, C.W., Saavedra, J., Baldo, E. Dahlquist, J., Pascua, I., and Fanning, C.M., 1998, The Famatinian magmatic arc in the central Sierras Pampeanas: An Early to Mid-Ordovician continental arc on the Gondwanan margin, in Pankhurst, R.J., and Rapela, C.W., eds., The Proto-Andean Margin of Gondwana: Geological Society of London Special Publication 142, p. 343-367.

Paquette, L., Ménot, R.P., and Peucat, J.J., 1989, REE, Sm$\mathrm{Nd}$ and $\mathrm{U}-\mathrm{Pb}$ zircon study of eclogites from the Alpine External massifs (western Alps): Evidence for crustal contamination: Earth and Planetary Science Letters, v. 96, p. 181-198, doi:10.1016/0012-821X(89)90131-3.

Parga Pondal, I., Matte, P., and Capdevila, R., 1964, Introduction à la géologie de l'Ollo do Sapo Formation, porphyroïde antesilurienne du nord-ouest de l'Espagne: Notas y Comunicaciones del Instituto Geológico y Minero de España, v. 76, p. 119-154.

Pereira, M.F., Silva, J.B., Chichorro, M., Moita, P., Santos, J.F., Apraiz, A., and Ribeiro, C., 2007, Crustal growth and deformational processes in the northern Gondwana margin: Constraints from the Evora Massif (Ossa-Morena zone, southwest Iberia, Portugal), in Linnemann, U., Nance, R.D., Kraft, P., and Zulauf, G., eds., The Evolution of the Rheic Ocean: From Avalonian-Cadomian Active Margin to Alleghenian-Variscan Collision: Geological Society of America Special Paper 423, p. 333-358.

Pfiffner, O.A., Lehner, P., Heitzmann, P., Müller, S., and Steck, A., eds., 1996, Deep Structure of Switzerland Results from the National Research Program Volume 20: Basel, Birkhàuser, 380 p.

Plogmann, H., 1973, Zur Geologie und Petrographie der Regionen Sanabria (Prov. Zamora) und Calvera Baja (Prov. León) in NW Spanien [Ph.D. thesis]: Mathematisch-Naturwissenschaftliche Fakultät Universität Münster, Germany, $168 \mathrm{p}$

Poller, U., 1997, U-Pb single zircon study of gabbroic and granitoid rocks of Val Barlas-ch (Silvretta nappe, Switzerland): Schweizerische Mineralogische und Petrographische Mitteilungen, v. 77, p. 351-359.

Poller, U., Nägler, T.F., Liebetrau, V., and Galetti, G., 1997, The Mönchalpgneiss-Geochemical characteristics and Sm-Nd data of a polymetamorphic S-type granitoid (Silvretta nappe/Switzerland): European Journal of Mineralogy, v. 9, p. 411-422.

Proyer, A., 2003, Metamorphism of pelites in NKFMASHA new petrogenetic grid with implications for the preservation of high-pressure mineral assemblages during exhumation: Journal of Metamorphic Geology, v. 21, p. 493-509, doi:10.1046/j.1525-1314.2003.00457.x.

Putiš, M., Ivan, P., Milan Kohút, M., Spišiak, J., Siman, P., Radvanec, M., Uher, P., Sergeev, S., Larionov, A., Méres, Š., Demko, R., and Ondrejka, M., 2009, Metaigneous rocks of the West-Carpathian basement, Slovakia: Indicators of early Paleozoic extension and shortening events: Bulletin de la Société Géologique de France, v. 180, p. 461-471, doi:10.2113/gssgfbull.180.6.461.

Rast, N., and Skehan, J.W., 1983, The evolution of the Avalonian plate: Tectonophysics, v. 100, p. 257-286, doi:10.1016/0040-1951(83)90191-9.

Robardet, M., 2003, The Armorica "microplate": Fact of fiction? Critical review of the concept and contradictory palaeobiogeographical data: Palaeogeography, Palaeoclimatology, Palaeoecology, v. 195 , p. $125-148$, doi 10.1016/S0031-0182(03)00305-5.

Rode, S., Rösel, D., and Schulz, B., 2012, Constraints on the Variscan $P-T$ evolution by EMP Th-U-Pb monazite dating in the polymetamorphic Austroalpine Oetztal-Stubai basement (eastern Alps): Zeitschrift der Deutschen Gesellschaft für Geowissenschaften, v. 163 p. 43-67, doi:10.1127/1860-1804/2012/0163-0043.

Rodríguez Alonso, M.D., Peinado, M., López-Plaza, M., Franco, P., Carnicero, A., and Gonzalo, J.C., 2004, Neoproterozoic-Cambrian synsedimentary magmatism in the Central Iberian zone (Spain): Geology, petrology and geodynamic significance: International Journal of Earth Sciences, v. 93, p. 897-920, doi:10.1007 /s00531-004-0425-4. 
Roger, F., Respaut, J.P., Brunel, M., Matte, Ph., and Paquette, J.L., 2004, Première datation U-Pb des orthogneiss oeillés de la zone axiale de la Montgane Noire (Sud du Massif central): Nouveaux témoins du magmatisme ordovicien dans la chaîne varisque: Comptes Rendus de l'Académie des Sciences, Geoscience, v. 336, p. 19-28, doi:10.1016/j.crte.2003.10.014

Röllig, G., Kampe, A., Steinbach, V., Ehling, B.-C., and Wasternack, J., 1995, Der Untergrund des Mitteldeutschen Braunkohlereviers: Zeitschrift der Geologischen Wissenschaften, v. 23, p. 3-26.

Rossi, P., Oggiano, G., and Cocherie, A., 2009, A restored section of the "southern Variscan realm" across the Corsica-Sardinia microcontinent: Comptes Rendus de l'Académie des Sciences, Geoscience, v. 341, p. 224 238, doi:10.1016/j.crte.2008.12.005.

Rubatto, D., Schaltegger, U., Lombardo, B., Colombo, F., and Compagnoni, R., 2001, Complex Paleozoic magmatic and metamorphic evolution in the Argentera massif (western Alps) resolved with U-Pb dating: Schweizerische Mineralogische und Petrographische Mitteilungen, v. 81, p. 213-228.

Rubatto, D., Ferrando, S., Compagnoni, R., and Lombardo, B., 2010, Carboniferous high-pressure metamorphism of Ordovician protoliths in the Argentera Massif (Italy), southern European Variscan belt: Lithos, v. 116, p. 65-76, doi:10.1016/j.lithos.2009.12.013.

Rubio-Ordóñez, A., Valverde-Vaquero, P., Corretgé, L.G., Cuesta-Fernández, A., Gallastegui, G., FernándezGonzález, M., and Gerdes, A., 2012, An Early Ordovician tonalitic-granodioritic belt along the Schistose-Greywacke domain of the Central Iberian zone (Iberian Massif, Variscan belt): Geological Magazine, doi:10.1017/S0016756811001129 (in press).

Rutishauser, H., 1973, Die quantitative Erfassung von Migmatiten im Aufschlussbereich (erläutert am Beispiel des Lauterbrunner Kristallins): Schweizerische Mineralogische und Petrographische Mitteilungen, v. 53, p. 99-124.

Sánchez García, T., Bellido, F., and Quesada, C., 2003, Geodynamic setting and geochemical signatures of Cambrian-Ordovician rift-related igneous rocks (OssaMorena zone, SW Iberia): Tectonophysics, v. 365, p. 233-255, doi:10.1016/S0040-1951(03)00024-6.

Sánchez Martínez, S., Arenas, R., Fernández Suárez, J., and Jeffries, T.E., 2009, From Rodinia to Pangea: Ophiolites from NW Iberia as witness for a long-lived continental margin, in Murphy, J.B., Keppie, J.D., and Hynes, A.J., eds., Ancient Orogens and Modern Analogues: Geological Society of London Special Paper 327, p. 317-341.

Sánchez Martínez, S., Gerdes, A., Arenas, R., and Abati, J., 2012, The Bazar ophiolite of NW Iberia: A relic of the Iapetus-Tornquist Ocean in the Variscan suture: Terra Nova, v. 24, p. 283-294, doi:10.1111/j.1365 $-3121.2012 .01061 . x$.

Schäfer, G., 1969, Geologie und Petrographie im östlichen Kastilischen Hauptscheidegebirge (Sierra de Guadarrama, Spanien): Münstersche Forschungen zur Geologie und Paläontologie, v. 10, 207 p.

Schaltegger, U., 1993, The evolution of the polymetamorphic basement in the central Alps unraveled by precise U-Pb zircon dating: Contributions to Mineralogy and Petrology, v. 113, p. 466-478, doi:10.1007/BF00698316.

Schaltegger, U., ed., 1997a, Geology and evolution of the Proterozoic-Paleozoic basement in the Alps: Schweizerische Mineralogische und Petrographische Mitteilungen, v. 77 , no. 3 , p. $261-437$.

Schaltegger, U., 1997b, Magma pulses in the Central Variscan belt: Episodic melt generation and emplacement during lithospheric thinning: Terra Nova, v. 9, p. 242245, doi:10.1111/j.1365-3121.1997.tb00021.x.

Schaltegger, U., 1997c, The age of an Upper Carboniferous/ Lower Permian sedimentary basin and its hinterland as constrained by U-Pb dating of volcanic and detrital zircons (northern Switzerland): Schweizerische Mineralogische und Petrographische Mitteilungen, v. 77, p. $101-111$.

Schaltegger, U., 2000, U-Pb geochronology of the Southern Black Forest batholith (Central Variscan belt): Timing of exhumation and granite emplacement: International Journal of Earth Sciences, v. 88, p. 814-828, doi: $10.1007 / \mathrm{s} 005310050308$.
Schaltegger, U., and Corfu, F., 1995, Late Variscan "basin and range" magmatism and tectonics in the central Alps: Evidence from $\mathrm{U}-\mathrm{Pb}$ geochronology: Geodinamica Acta, v. 8, p. 82-98.

Schaltegger, U., and Gebauer, D., 1999, Pre-Alpine geochronology of the central, western and southern Alps: Schweizerische Mineralogische und Petrographische Mitteilungen, v. 79, p. 79-87.

Schaltegger, U., Schneider, J.L., Maurin, J.C., and Corfu, F., 1996, Precise U-Pb chronometry of 345-340 Ma old magmatism related to syn-convergence extension in the southern Vosges (Central Variscan belt): Earth and Planetary Science Letters, v. 144, p. 403-419, doi:10.1016/S0012-821X(96)00187-2.

Schaltegger, U., Nägler, Th.N., Corfu, F., Maggetti, M., Galetti, G., and Stosch, H., 1997, A Cambrian island arc in the Silvretta nappe: Constraints from geochemistry and geochronology: Schweizerische Mineralogische und Petrographische Mitteilungen, v. 77, p. 337-350.

Schaltegger, U., Fanning, C.M., Günther, D.M., Maurin, J.C., Schulmann, K., and Gebauer, D., 1999, Growth, annealing and recrystallization of zircon and preservation of monazite in high-grade metamorphism Conventional and in-situ U-Pb isotope, cathodoluminescence and microchemical evidence: Contributions to Mineralogy and Petrology, v. 134, p. 186-201, doi:10.1007/s004100050478.

Schaltegger, U., Gebauer, D., and von Quadt, A., 2002, The mafic-ultramafic rock association of Loderio-Biasca (lower Pennine nappes, Ticino, Switzerland): Cambrian oceanic magmatism and its bearing on early Paleozoic paleogeography: Chemical Geology, v. 186, p. 265 279, doi:10.1016/S0009-2541(02)00005-0.

Schaltegger, U., Abrecht, J., and Corfu, F., 2003, The Ordovician orogeny in the Alpine basement: Constraints from geochronology and geochemistry in the Aar Massif (central Alps): Schweizerische Mineralogische und Petrographische Mitteilungen, v. 83, p. 183-195.

Schätz, M., Tait, J., and Bachtadse, V., 2002, Palaeozoic geography of the Alpine realm, new palaeomagnetic data from the Northern Greywacke zone, eastern Alps: International Journal of Earth Sciences, v. 91, p. 979992, doi:10.1007/s00531-002-0289-4.

Schmid, S.M., Fügenschuh, B., Kissling, E., and Schuster, R., 2004, Tectonic map and overall architecture of the Alpine orogen: Eclogae Geologicae Helvetiae, v. 97, p. $93-117$.

Schönlaub, H.P., ed., 1997, Guidebook, IGCP Project 421, North Gondwanan Mid-Palaeozoic Biodynamics, Vienna 1997: Wien, Berichte der Geologischen Bundesanstalt, v. 40, 134 p.

Schönlaub, H.P., and Heinisch, H., 1993, The classic, fossiliferous Palaeozoic units of the eastern and southern Alps, in von Raumer, J., and Neubauer, F., eds., The Pre-Mesozoic Geology in the Alps: Heidelberg, Germany, Springer, p. 395-422.

Schönlaub, H.P., Ferretti, A., Gaggero, L., Hammarlund, E. Harper, D.A.T., Histon, K., Priewalder, H., Spötl, C. and Štorch, P., 2011, The Late Ordovician glacial event in the Carnic Alps (Austria), in Gutiérrez-Marco, J.C., Rábano, I., and García-Bellido, D., eds., The Ordovician of the World: Madrid, Instituto Geológico y Minero de España, Cuadernos del Museo Geominero, v. 14, p. 517.

Schulmann, K., Schaltegger, U., Jezek, J., Thompson, A.B., and Edel, J.B., 2002, Rapid burial and exhumation during orogeny: Thickening and synconvergent exhumation of thermally weakened and thinned crust (Variscan orogen in Western Europe): American Journal of Science, v. 302, p. 856-879, doi:10.2475/ajs.302.10.856.

Schulmann, K., Konopasek, J., Janousek, V., Lexa, O., Lardeaux, J.M., Edel, J.-B., Stipska, P., and Ulrich, St., 2009, An Andean type Palaeozoic convergence in the Bohemian Massif: Comptes Rendus de l'Académie des Sciences, Geoscience, v. 341, p. 266-286, doi: 10.1016/j.crte.2008.12.006

Schulz, B., 2008, Basement of the Alps, in McCann, T., ed., Geology of Central Europe, Volume 1: Precambrian and Paleozoic: London, Geological Society of London, p. 79-83.

Schulz, B., and Bombach, K., 2003, Single zircon $\mathrm{Pb}-\mathrm{Pb}$ geochronology of the early-Palaeozoic magmatic evolution in the Austroalpine basement to the south of the
Tauern Window: Jahrbuch der Geologischen Bundesanstalt, v. 143, p. 303-321.

Schulz, B., and von Raumer, J., 2011, Discovery of Ordovician-Silurian metamorphic monazite in garne metapelites of the Alpine External Aiguilles Rouges Massif: Swiss Journal of Geosciences, v. 104, p. 6779, doi:10.1007/s00015-010-0048-7.

Schulz, B., Bombach, K., Pawlig, S., and Braetz, H., 2004 Neoproterozoic to early-Palaeozoic magmatic evolution in the Gondwana-derived Austroalpine basement to the south of the Tauern Window (eastern Alps): International Journal of Earth Sciences, v. 93, p. 824 843, doi:10.1007/s00531-004-0421-8

Schulz, B., Steenken, A., and Siegesmund, S., 2008, Geodynamic evolution of an Alpine terrane-The Austroalpine basement to the south of the Tauern Window as a part of the Adriatic plate (eastern Alps), in Siegesmund, S., Fügenschuh, B., and Froitzheim, N., eds. Tectonic Aspects of the Alpine-Dinaride-Carpathian System: Geological Society of London Special Publication 298 , p. 5-44.

Schuster, R., Scharbert, S., Abart, R., and Frank, W., 2001, Permo-Triassic extension and related HT/LP metamorphism in the Austroalpine-Southalpine realm: Mitteilungen der Gesellschaft für Geologische Bergbaustudien in Österreich, v. 45, p. 111-141.

Seifert, W., Rhed, D., Thomas, R., Förster, H.-J., Lucassen, F., Dulski, P., and Wirth, R., 2011, Distinctive properties of rock-forming blue quartz: Inferences from a multi-analytical study of submicron mineral inclusions: Mineralogical Magazine, v. 75, p. 2519-2534, doi:10.1180/minmag.2011.075.4.2519.

Siegesmund, S., Heinrichs, T., Romer, R.L., and Doman, D., 2007, Age constraints on the evolution of the Austroalpine basement to the south of the Tauern Window: International Journal of Earth Sciences, v. 96, p. 415432, doi:10.1007/s00531-006-0115-5.

Solá, A.R., Pereira, M.F., Williams, I.S., Ribeiro, M.L., Neiva, A.M.R., Montero, P., Bea, F., and Zinger, T., 2008, New insights from U-Pb zircon dating of Early Ordovician magmatism on the northern Gondwana margin: The Urra Formation (SW Iberian Massif, Portugal): Tectonophysics, v. 461, p. 114-129, doi: 10.1016/j.tecto.2008.01.011

Stampfli, G.M., 1996, The intra-Alpine terrain: A Palaeotethyan remnant in the Alpine Variscides: Eclogae Geologicae Helvetiae, v. 89, p. 12-42.

Stampfli, G.M., ed., 2001, Geology of the Western Swiss Alps, a Guide Book: Mémoires de Géologie (Lausanne), v. $36,195 \mathrm{p}$.

Stampfli, G.M., 2012, The geodynamics of Pangea formation: Géologie de la France, v. 2012, p. 206-209.

Stampfli, G.M., and Borel, G.D., 2002, A plate tectonic model for the Paleozoic and Mesozoic constrained by dynamic plate boundaries and restored synthetic oceanic isochrones: Earth and Planetary Science Letters, v. 196, p. 17-33, doi:10.1016/S0012-821X(01)00588-X.

Stampfli, G.M., and Borel, G.D., 2004, The TRANSMED transects in space and time: Constraints on the paleotectonic evolution of the Mediterranean domain, $i$ Cavazza, W., Roure, F., Spakman, W., Stampfli, G.M., and Ziegler, P., eds., The TRANSMED Atlas: The Mediterranean Region from Crust to Mantle: Berlin, Springer, p. 53-80.

Stampfli, G.M., and Hochard, C., 2009, Plate tectonics of the Alpine realm, in Murphy, J.B., Hynes, A.J., and Keppie, J.D., eds., Ancient Orogens and Modern Analogues: Geological Society of London Special Publication 327 , p. 89-111.

Stampfli, G.M., and Kozur, H., 2006, Europe from the Variscan to the Alpine cycles, in Gee, D.G., and Stephenson, R., eds., European Lithosphere Dynamics: Geological Society of London Memoir 32, p. 57-82.

Stampfli, G.M., von Raumer, J., and Borel, G., 2002, The Paleozoic evolution of pre-Variscan terranes: From Gondwana to the Variscan collision, in Martínez Catalán, J.R., Hatcher, R.D., Jr., Arenas, R., and Díaz García, F., eds., Variscan Appalachian Dynamics: The Building of the Late Paleozoic Basement: Geological Society of America Special Paper 364, p. 263-280.

Stampfli, G.M., Vavassis, I., De Bono, A., Rosselet, F., Matti, B., and Bellini, M., 2003, Remnants of the Paleotethys 
oceanic suture-zone in the western Tethyan area, in Cassinis, G., and Decandia, F.A., eds, Stratigraphic and Structural Evolution on the Late Carboniferous to Triassic Continental and Marine Successions in Tuscany (Italy): Regional Reports and General Correlation: Bolletino della Società Geologica Italiana, special volume 2, p. 1-24.

Stampfli, G.M., Hochard, C., and von Raumer, J.F., 2006 Reconstructing the Palaeozoic Gondwana margin an its redistribution: New aspects: Geophysical Research Abstracts, v. 8, p. EGU06-A-02708.

Stampfli, G.M., von Raumer, J., and Wilhem, C., 2011, The distribution of Gondwana derived terranes in the early Paleozoic, in Gutiérrez-Marco, J.C., Rábano, I., an García-Bellido, D., eds, The Ordovician of the World: Madrid, Instituto Geológico y Minero de España, Cuadernos del Museo Geominero, v. 14, p. 567-574.

Starijaš, B., Gerdes, A., Balen, D., Tibljas, D., and Finger, F., 2010, The Moslavacka Gora crystalline massif in Croatia: A Cretaceous heat dome within remnant Ordovician granitoid crust: Swiss Journal of Geosciences, v. 103, p. 61-82, doi:10.1007/s00015-010-0007-3.

Steck, A., Epard, J.L., Escher, A., Gouffon, Y., and Masson, H., eds., 2001, Carte Tectonique des Alpes de Suisse Occidentale. Note Explicative : Bern, Switzerland, Office Fédéral des Eaux et de la Géologie Carte Géologique Spéciale 123, scale 1:100,000, 4 sheets.

Tabaud, A., Rossi, P., Whitechurch, H., Schulmann, K. Skrzypek, E., Guerrot, C., and Paquette, J.L., 2012, The Visean $\mathrm{Mg}-\mathrm{K}$ magmatism as the result of the in volvement of radiogenic heat production in the Variscan internal ("Moldanubian") zone: Evidence from the Vosges Mts (NE France): Géologie de la France, v. 2012, p. 210-211.

Thöni, M. 1999, A review of geochronological data from the eastern Alps: Schweizerische Mineralogische und Petrographische Mitteilungen, v. 79, p. 209-230.

Thöny, W.F., Tropper, P., Schennach, F., Krenn, E., Finger, F., Kaindl, R., Bernhard, F., and Hoinkes, G., 2008, The metamorphic evolution of migmatites from the Ötztal complex (Tyrol, Austria) and constraints on the timing of the pre-Variscan high- $T$ event in the eastern Alps: Swiss Journal of Geosciences, v. 101, supplement 1, p. 111-126, doi:10.1007/s00015-008-1290-0.

Trombetta, A., Cirrincione, R., Corfu, F., Mazzoleni, P., and Pezzino, A., 2004, Mid-Ordovician U-Pb ages of porphyroids in the Peloritan Mountains (NE Sicily): Palaeogeographical implications for the evolution of the Alboran microplate: Journal of the Geological Society of London, v. 161, p. 265-276, doi:10.1144 /0016-764903-068.

Trümpy, R., Bernoulli, D., Grünenfelder, M., Képpel, V., Müller, St., and Trommsdorf, V., 1980, Geology of Switzerland-A Guide-Book Part A: An Outline of the Geology of Switzerland (Schweizerische Geologische Kommission, ed.): Basel, Wepf \& Co. Publishers, 104 p.
Valverde-Vaquero, P., and Dunning, G.R., 2000, New U-Pb ages for Early Ordovician magmatism in central Spain: Journal of the Geological Society of London, v. 157, p. 15-26, doi:10.1144/jgs.157.1.15.

Veselá, P., Söllner, F., Finger, F., and Gerdes, A., 2011, Magmato-sedimentary Carboniferous to Jurassic evolution of the western Tauern Window, eastern Alps (constraints from $\mathrm{U}-\mathrm{Pb}$ zircon dating and geochemistry): International Journal of Earth Sciences, v. 100, p. $993-$ 1027, doi:10.1007/s00531-010-0596-0.

von Quadt, A., Günther, D., Frischknecht, R., Zimmermann, R., and Franz, G., 1997, The evolution of pre-Variscan eclogites of the Tauern Window (Eastern Alps): A $\mathrm{Sm} / \mathrm{Nd}$-, conventional and Laser ICP-MS zircon U-Pb study: Schweizerische Mineralogische und Petrographische Mitteilungen, v. 77, p. 265-279.

von Raumer, J.F, 1971, Das Mont-Blanc-Massiv-Altkristallin im Bereich schwacher alpiner Metamorphose: Schweizerische Mineralogische und Petrographische Mitteilungen, v. 51, p. 193-225.

von Raumer, J.F., 1976, Le massif du Mont Blanc, socle prépermien dans un cadre alpin: Bulletin de la Société Fribourgeoise des Sciences Naturelles, v. 65, p. 123-155.

von Raumer, J.F., 1998, The Palaeozoic evolution in the Alps-From Gondwana to Pangea: Geologische Rundschau, v. 87, p. 407-435, doi:10.1007/s005310050219.

von Raumer, J.F., and Bussy, F., 2004, Mont-Blanc and Aiguilles-Rouges: Geology of their polymetamorphic basement (External massifs, France-Switzerland): Mémoires de Géologie (Lausanne), v. 42, p. 1-203.

von Raumer, J.F., and Neubauer, F., eds., 1993, The PreMesozoic Geology in the Alps: Heidelberg, Germany, Springer, $677 \mathrm{p}$.

von Raumer, J., and Stampfli, G.M., 2008, The birth of the Rheic Ocean-Early Palaeozoic subsidence patterns and tectonic plate scenarios: Tectonophysics, v. 461, p. 9-20, doi:10.1016/j.tecto.2008.04.012.

von Raumer, J.F., Stampfli, G.M., Borel, G., and Bussy, F., 2002, The organization of pre-Variscan basement areas at the north-Gondwanan margin: International Journal of Earth Sciences, v. 91, p. 35-52, doi:10.1007 /s005310100200.

von Raumer, J.F., Stampfli, G.M., and Bussy, F., 2003, Gondwana-derived microcontinents: The constituents of the Variscan and Alpine collisional orogens: Tectonophysics, v. 365 , p. 7-22, doi:10.1016/S0040-1951 (03)00015-5

von Raumer, J.F., Stampfli, G.M., Hochard, C., and Gutiérrez-Marco, J.C., 2006, The Early Palaeozoic in Iberia-A plate-tectonic interpretation: Zeitschrift der Deutschen Gesellschaft für Geowissenschaften, v. 157, p. 575-584, doi:10.1127/1860-1804/2006/0157-0575.

von Raumer, J., Bussy, F., and Stampfli, G., 2009, The Variscan evolution in the Alps-and place in their Variscan framework: Comptes Rendus de l'Académie des Sciences, Geosciences, v. 341, p. 239-252. von Raumer, J., Bussy, F., and Stampfli, G.M., 2011, Les Alpes paléozoïques-De la marge de Gondwana à la collision varisque: Géochronique, v. 137, p. 34-37.

von Raumer, J.F., Janoušek, V., and Stampfli, G.M., 2012, Durbachites-vaugnerites-A time-marker across the European Variscan basement: Géologie de la France, v. 2012 , p. $178-180$.

Wilhem, C., 2010, Plate Tectonics of the Altaids [Ph.D. thesis] Lausanne, Switzerland, University of Lausanne, 347 p.

Winchester, J.A., Patoĉka, F., Kachlik, V., Melzer, M., Nawakowski, C., Crowley, Q.G., and Floyd, P.A., 2003, Geochemical discrimination of metasedimentary sequences in the Krkonose-Jisera terrane (West Sudetes, Bohemian Massif): Geologica Carpathica, v. 54, p. 267-280.

Wu, Cai-Lai, Wooden, N.J.L., Robinson, P.T., Gao, YunHong, Wu, Suo-Ping, Chen, Qi-Long, Mazdab, F.K. and Mattinson, C., 2009, Geochemistry and zircon SHRIMP U-Pb dating of granitoids from the west seg ment of the North Qaidam: Science in China Series D, Earth Sciences, v. 52, p. 1771-1790.

Žák, J., Holub, F. V, and Verner, K, 2005, Tectonic evolution of a continental magmatic arc from transpression in the upper crust to exhumation of mid-crustal orogenic roo recorded by episodically emplaced plutons: The Central Bohemian plutonic complex (Bohemian Massif): International Journal of Earth Sciences, v. 94, p. 385-400, doi:10.1007/s00531-005-0482-3.

Ziegler, P., 1984, Caledonian and Hercynian crustal consolidation of western and central Europe - A working hypothesis: Geologie en Mijnbouw, v. 63, p. 93-108.

Zulauf, G., Schitter, F., Riegler, G., Finger, F., Fiala, J., and Vejnar, Z., 1999, Age constraints on the Cadomian evolution of the Teplá Barrandian unit (Bohemian Massif) through electron microprobe dating of metamorphic monazite: Zeitschrift der Deutschen Geologischen Gesellschaft, v. 150, p. 627-639.

Zurbriggen, R., Franz, L., and Handy, M., 1997, Pre-Variscan deformation, metamorphism and magmatism in the Strona-Ceneri zone (southern Alps of northern Italy and southern Switzerland): Schweizerische Mineralogische und Petrographische Mitteilungen, v. 77, p. 361-381.

Zwart, H.J., and Dornsiepen, U.F., 1978, The tectonic ramework of Central and Western Europe: Geologie en Mijnbouw, v. 57, p. 627-654. 